\title{
The Ngorongoro Crater as the biggest geotouristic attraction of the Gregory Rift (Northern Tanzania, Africa) - geotouristic valorization, touristic development and hazard
}

\author{
Krater Ngorongoro największą atrakcją geoturystyczną ryftu Gregory'ego
}

(północna Tanzania, Afryka) - waloryzacja geoturystyczna, zagospodarowanie turystyczne i zagrożenia

\author{
Jerzy Żaba ${ }^{1}$, Krzysztof Gaidzik ${ }^{2}$ \\ ${ }^{1,2}$ University of Silesia, Faculty of Earth Sciences, Department of Fundamental Geology \\ ul. Będzińska 60, 41-200 Sosnowiec; \\ e-mail:1jerzy.zaba@us.edu.pl,k.gaidzik@gmail.com
}
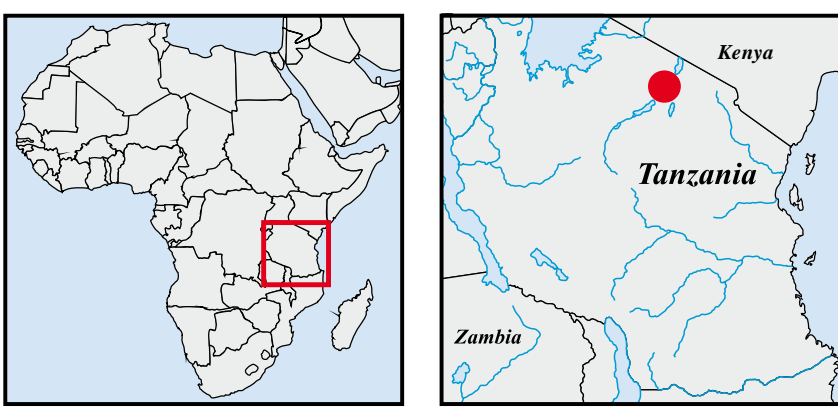

Abstract: The Ngorongoro Crater, as the largest unflooded and not destroyed volcanic caldera on Earth, is one of the major geotouristic attractions of East Africa. Unique on the global scale richness of wildlife, exotic cultures of indigenous people and specific position of the Crater within the East African Rift System, each year attracts thousands of tourists eager for an unforgetable. experience. Their number continues to grow from year to year, reaching the value of nearly half a million visitors within the last few years. Constantly developing tourism industry, besides many advantages, also causes a number of risks, both for the world of living nature and inanimate nature objects, as well as for the local population. In 1959, recognizing the unique and special touristic and geoeducative values of this location, the Ngorongoro Conservation Area (NCA) was established. Almost twenty years later, in 1978, the area was included in the UNESCO World Cultural and Natural Heritage List. Furthermore, within the Ngorongoro Conservation Area as well as in its immediate neighborhood there are many objects that also deserve to be called geotouristic attractions, such as: Olduvai Gorge, Crater Olmoti, Crater Empakai and Oldoinyo Lengai volcano. In a relatively short distance from the Crater also the highest mountain in Africa - the Kilimanjaro volcano and the biggest active volcano of this continent, Meru, are located.

Keywords: volcanoes, Ngorongoro, Gregory Rift, East African Rift System, Tanzania, geotouristc attractions, hazards

Treść: Krater Ngorongoro, jako największa niezalana i niezniszczona kaldera wulkaniczna na Ziemi, stanowi jedna z najważniejszych atrakcji geoturystycznych Afryki Wschodniej. Wyjatkowe bogactwo przyrody ożywionej, egzotyka kultury ludności autochtonicznej oraz unikalna pozycja krateru w obrębie wschodnioafrykańskiego systemu ryftowego, przyciaga każdego roku ogromne rzesze turystów żądnych niezapomnianych przeżyć. Ich liczba każdego roku stale rośnie, osiagajac w ostatnim okresie prawie pót miliona odwiedzajacych. Wzmożony i stale nasilający się ruch turystyczny ma wiele zalet, lecz powoduje również szereg zagrożeń, zarówno dla świata przyrody ożywionej, jak i nieożywionej, a także dla ludności lokalnej. W roku 1959, w uznaniu szczególnych walorów turystycznych i geoedukacyjnych krateru i jego okolicy ustanowiono tam Obszar Chroniony Ngorongoro (NCA). W roku 1978 obszar ten wpisano także na Listę Obiektów Światowego Dziedzictwa Kulturowego i Przyrodniczego UNESCO. Zarówno na Obszarze Chronionym Ngorongoro, jak też w jego najbliższym sąsiedztwie znajduje się bardzo wiele obiektów, które ze wszech miar zastuguja na miano atrakcji geoturystycznych; należą do nich m.in.: wąwóz Olduvai, krater Olmoti, krater Empakai badź wulkan Oldoinyo Lengai. W stosunkowo niewielkiej odległości od krateru Ngorongoro znajduje się najwyższa góra Afryki - wulkan Kilimandżaro oraz największy czynny wulkan tego kontynentu-Meru.

Slowa kluczowe: wulkany, Ngorongoro, ryft Gregory'ego, wschodnioafrykański system ryftowy, Tanzania, atrakcje geoturystyczne, zagrożenia

\section{Introduction}

The Ngorongoro Crater provides unforgetable. experience to every visitor. The truly magical Garden of Eden with thousands wild animals and numerous, often unique plant species, including endemic ones, attracts every year admirers of animate nature in its natural environment, apparently unspoiled by man and civilization (Fig. 1; Żaba, Gaidzik 2011a). Monument, majestic peaks of volcanic cones rising above the Crater Highlands and surrounding the Ngorongoro caldera enhance even more aesthetic feelings. Undoubted connotations with "The Lost World" of Sir Arthur Conan Doyle are provided by precipitous, vertical in places, walls of the caldera rising nearly $600 \mathrm{~m}$ above its floor, isolating thereby the "Ngorongoro world" from the rest of the globe.

However, the Ngorongoro Crater does not consist exclusively of animate nature. It is a peculiar example, on a global scale, of geological features and processes which are very important in Earth evolution (Żaba, Gaidzik 2011b). Ngorongoro represents the world-largest, not destroyed and unflooded, collapse volcanic caldera of an initially much higher than today (rising to ca. 5,000 $\mathrm{m}$ a.s.1.) vast shield volcano. Its activity commenced ca. 3-2 million years ago and lasted for nearly 250 thousands of years. 


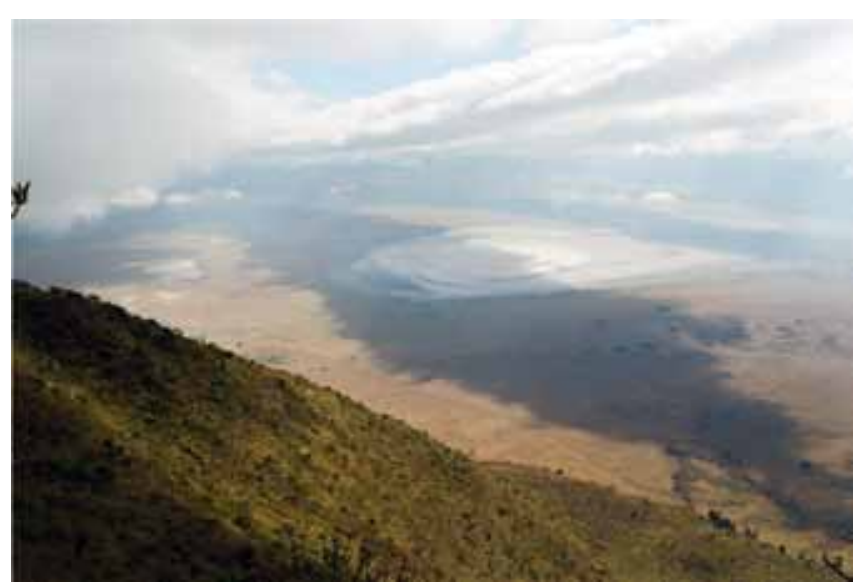

Fig. 1. The Ngorongoro Crater, view from the caldera's rim to its bottom situated ca. $600 \mathrm{~m}$ below, phot. J. Żaba $\bullet$ Krater Ngorongoro, widok z krawędzi kaldery na jej dno (leżące około $600 \mathrm{~m}$ poniżej), fot. J. Żaba

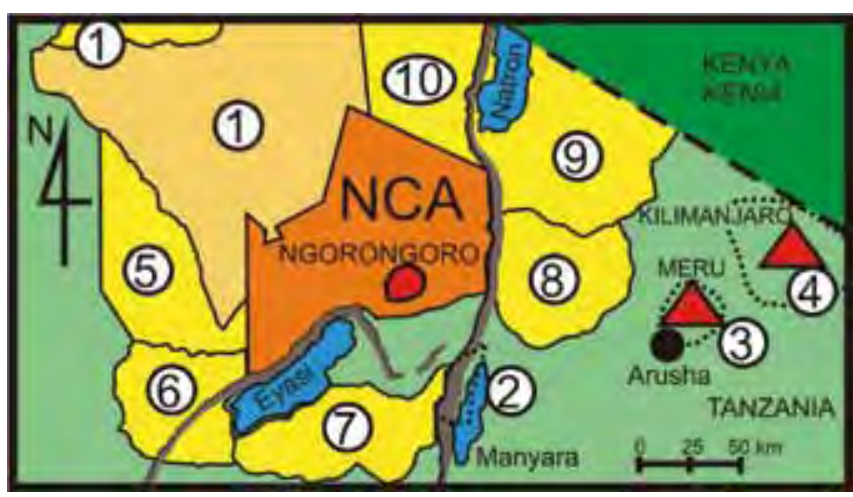

Fig. 2. The Ngorongoro Conservation Area (NCA) on the background of northern Tanzanian protected areas. 1 - Serengeti National Park, 2 - Lake Manyara National Park, 3 - Arusha National Park, 4 - Kilimanjaro National Park, 5 - Maswa Game Reserve, 6 - Makao Game Controlled Area, 7 - Mang'ola Game Controlled Area, 8 - Mto-Wa-Mbu Game Controlled Area, 9 - Lake Natron Game Controlled Area, 10 - Loliondo Game Controlled Area • Obszar Chroniony Ngorongoro (NCA) na tle parków i obszarów chronionych północnej Tanzanii. 1 - Park Narodowy Serengeti, 2 - Park Narodowy Jeziora Manyara, 3 - Park Narodowy Arusha, 4 - Park Narodowy Kilimanjaro, 5 - rezerwat przyrody Maswa, 6 - obszar chroniony Makao, 7 - obszar chroniony Mang'ola, 8 - obszar chroniony Mto-Wa-Mbu, 9 - obszar chroniony jeziora Natron, 10 - obszar chroniony Loliondo

The origin and evolution of this form has been strongly associated with rifting within the Gregory Rift, one of the best studied segments of the East African Rift System. It represents a failed rift arm, within which oceanic crust could not have been formed, despite visible traces of tectonic and related volcanic processes.

This paper is the last one from a series of three publications dealing with the Ngorongoro Crater, as the greatest geotouristic attraction of the Gregory Rift and, probably, of the entire East Africa. It focuses on tourist infrastructure, animate and inanimate nature protection measures, as well as possibilities and regulations of human activity in this area. Moreover, the paper provides data pertaining to present and future hazards related to exponentially increasing tourist traffic. The remaining two papers were devoted to natural conditions of the
Ngorongoro Crater. The first paper concerned geographical setting of the area (location and geomorphology, hydrological conditions, climate, animate nature, indigenous people; Żaba, Gaidzik 2011a), the second one dealt with geological setting and evolution of the Ngorongoro Crater in the East African Rift System (Żaba, Gaidzik 2011b).

\section{Geoconservation}

The urgent need of protection of the uniqueness of natural and cultural heritage of the Ngorongoro Crater was noticed relatively early. Already in the first half of the 20th century, the undoubted richness of wildlife of this area was taken into account when introducing a complete ban of game. In 1951, the Ngorongoro area was included into the newly-established Serengeti National Part (UNESCO/IUCN 2008). A crucial moment in the history of geoconservation of this area, however, took place in 1959 when the Ngorongoro Conservation Area (NCA) was established. Basic assumptions lying behind this decision represented a certain type of experiment. The NCA originated as the first multi-function protection area in East Africa, the aim of which was to provide peaceful coexistence of natural environment with local Maasai population (Estes et al. 2006). However, excessively intensive growth in the number of indigenous people and related agricultural and pastoral activity (herds numbering tens of thousands of cattle) posed increasingly growing threat to nearly all important natural elements within the Crater. Such a situation led to radical changes in management of the area by the Ngorongoro Conservation Area Authority (NCAA). In 1975, the Maasai population was resettled outside the Crater area and all agricultural activity was banned. Since that time, the Maasai have still leaved in the NCA, although the Ngorongoro caldera itself is free of permanent settlements (UNESCO/IUCN 2008).

The NCA occupies an area of $8,292 \mathrm{~km}^{2}$, i.e., less than $1 \%$ of Tanzanian territory, although the region is three times larger than, for instance, Luxembourg. Besides the caldera, undoubtedly the most important object within the NCA, the area embraces as well other extinct shield volcanoes of the Gregory Rift that are present in the Crater Highlands, like: Oldeani, Olmoti, Loolmalasin, Empakai, Kerimasi, and Makarot (cf. Żaba, Gaidzik 2011b), as well as the Doinyoogol Hills and Olduvai Gorge. Moreover, just near the boundary of NCA, the only active carbonatite volcano on Earth, Oldoinyo Lengai, is situated. The Ngorongoro Conservation Area occupies a peculiar position in northern Tanzania adjoining numerous terrains subject to protective measures of different rank (Fig. 2). It is bordered: 1 - on the west by the Serengeti National Park and Maswa Game Reserve, 2 - on the southwest by the Makao Game Controlled Area, 3 - on the south by Lake Eyasi with the Mang'ola Game Controlled Area, 4 - on the east by the Mto-Wa-Mbu Game Controlled Area and Lake Natron Game Controlled Area, and 5 - on the north by the Loliondo Game Controlled Area.

Not far to the east and southeast of the NCA, national parks of Manyara Lake, Arusha (including the highest active volcano of Africa-Meru), and Kilimanjaro (the highest peak of Africa) are located (Fig. 2). 
Taking into account natural richness of the Ngorongoro Crater, the area was recognized in 1981 as a Biosphere Reserve within the framework of the UNESCO Man and Biosphere Program (UNESCO/IUCN 2008) and as a global Area of Endemic Birds (Fishpool, Evans, eds. 2001). Moreover, the NCA belongs to the WWF Global 200 Freshwater Eco-regions (UNESCO/IUCN 2008).

In 1978, the Ngorongoro Crater was included in the UNESCO World Cultural and Natural Heritage List as an object of natural character (http://whc.unesco.org/en/). In this way, the undoubted richness of both animate and inanimate nature was appreciated, and particular importance of rifting and associated volcanic activity was underlined. With respect to extraordinary archaeological findings made in the last years in the Olduvai Gorge and Laetola area, the Committee for Global Heritage recognized and added on July 31st, 2010 the importance of cultural aspects for the NCA. At present, the NCA is qualified on the UNESCO list as a mixed object, fulfilling five from ten criteria (one cultural criterion no. IV and all natural criteria, i.e. nos. VII, VIII, IX and X; UNESCO, 2005). According to these criteria, applied by the UNESCO Committee for Global Heritage, the Ngorongoro Conservation Area fulfills the following conditions: criterion no. IV - represents an outstanding example of a type of building, architectural or technological ensemble or landscape which illustrates (a) significant stage(s) in human history; criterion no. VII - contains superlative natural phenomena or areas of exceptional natural beauty and aesthetic importance; criterion no. VIII - presents outstanding examples representing major stages of earth's history, including the record of life, significant on-going geological processes in the development of landforms, or significant geomorphic or physiographic features; criterion IX - represents outstanding examples representing significant on-going ecological and biological processes in the evolution and development of terrestrial, fresh water, coastal and marine ecosystems and communities of plants and animals; and criterion $\mathrm{X}$ - contains the most important and significant natural habitats for in-situ conservation of biological diversity, including those containing threatened species of outstanding universal value from the point of view of science or conservation.

\section{Tourist traffic}

The Ngorongoro Crater belongs to one of the most frequently visited tourist attractions of Tanzania due to the richness and diversity of its natural and cultural values as well as its presence in the UNESCO World Cultural and Natural Heritage List. Nearly $25 \%$ of all tourists visiting northern Tanzania travel to the Ngorongoro Conservation Area. During the last three decades, the number of tourists has risen nearly tenfold: from ca. 35 thousands in 1983 to nearly 360 thousands in 2006 (including more than 250 thousands of foreign visitors). The NCA authorities planned to increase the number of tourists to one million in 2010 (UNESCO/IUCN 2007).

The increase in the number of tourists visiting the Ngorongoro Crater is by no means accidental and results, first of all, from intensive efforts of the Ngorongoro Conservation
Area Authorities who constantly develop tourist infrastructure in this region. The very accurate and up to date official website of the NCA deserves appreciation (Fig. 3; http://www. ngorongorocrater.org/welcome.html). Data posted in this website enable potential tourists to obtain information pertaining to worth-seeing objects and get acquainted with the existing legal and organizational regulations. They also can obtain data related to the costs of accommodation and travel, local conditions, car rental, hiring a guide, as well as necessary equipment. It is also possible to ask its own, more or less detailed questions when the website data are not sufficient. A very important notice warns that visits to both the Ngorongoro Crater and Olduvai Gorge can only be made with a licensed guide. Tourists travelling to the NCA should also be protected by qualified and armed guards, mainly due to the threat posed by predator mammals living in this area (Figs. 4, 5, 6).

Three roads marked out and adapted to the needs of tourist traffic (Figs. 7, 8) go to the caldera's floor:

- Seneto - an exclusively downhill road,

- Lerai - an uphill road, and

- Lemala (Sopa) - a road, along which both downhill and uphill traffic is allowed.

On caldera's floor, a number of mutually intersecting roads were marked out that enable the tourists to reach all interesting and worth-seeing places (Fig. 7). Travel is only allowed by rented, specially adapted cars (Fig. 9). Such cars provide shelter against numerous dangerous animals that live in the caldera (Figs. 6, 10), enabling at the same time safe consumption of meals and taking photographs (Figs. 11, 12, 13).

The Crater rim bears five lodges (Fig. 7): Serena Lodge, Crater Lodge, Rhino Lodge, Wildlife Lodge (Fig. 14), and Sopa Lodge. These objects provide altogether more than 500 accommodation places (UNESCO, 2005). Moreover, the Crater rim houses a few specifically designated campsites (Fig. 7). The NCA territory is also equipped with tourist information centres (Figs. 15, 16) and specially designated scenic points, from which one can admire the majestic panorama of the "Ark of Africa" (Figs. 7, 17).

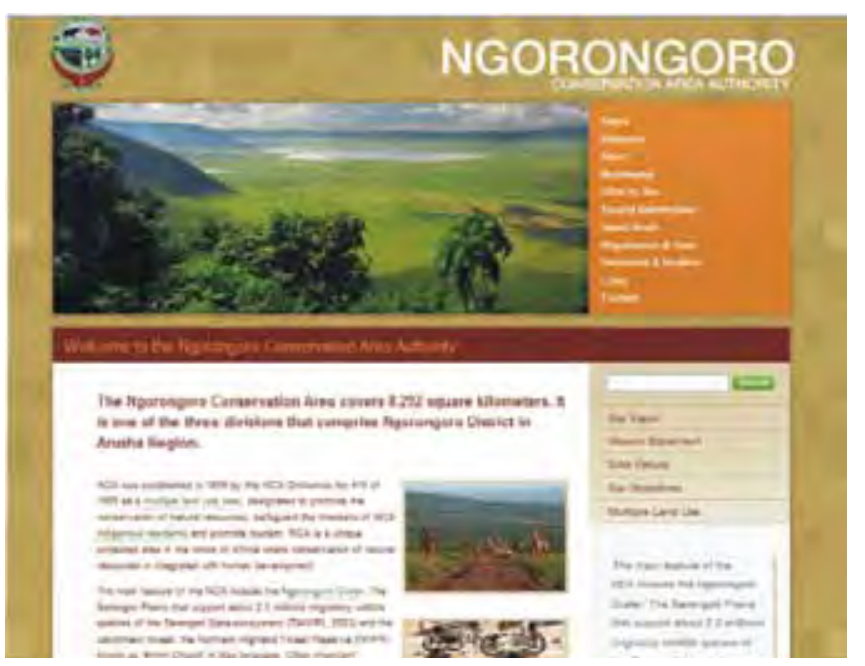

Fig. 3. Official website of the Ngorongoro Conservation Area (NCA; www.ngorongorocrater.org/welcome.html) $\bullet$ Oficjalna strona internetowa Obszaru Chronionego Ngorongoro (NCA; www.ngorongorocrater.org/welcome.html) 


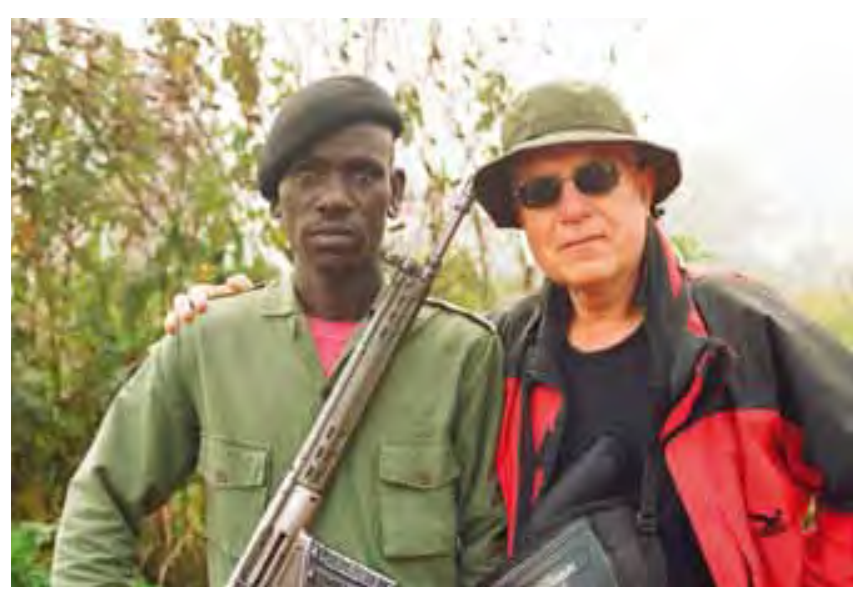

Fig. 4. Armed Maasai guard from the Ngorongoro Conservation Area together with Jerzy Żaba, phot. J. Żaba • Jerzy Żaba w towarzystwie masajskiego strażnika na Obszarze Chronionym Ngorongoro, fot. J. Żaba

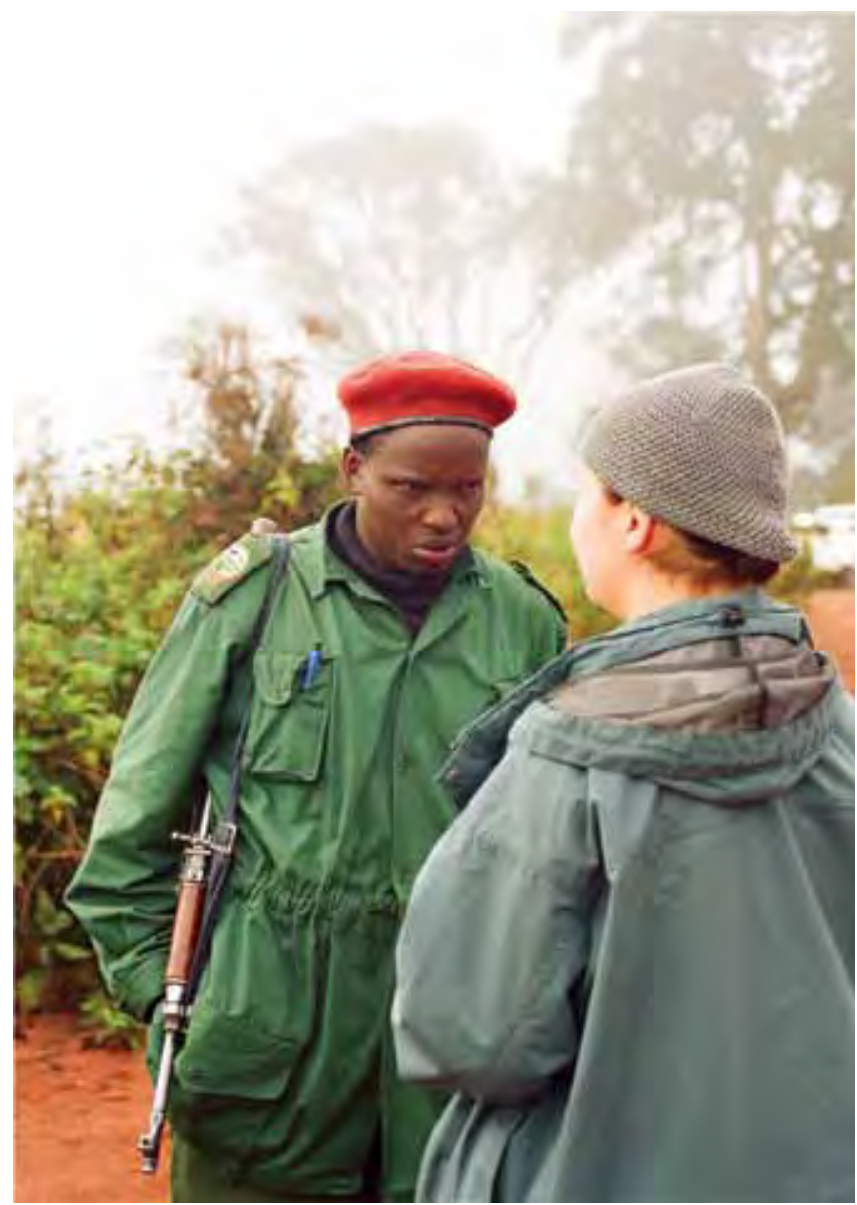

Fig. 5. A Maasai guard from the Ngorongoro Conservation Area warning a tourist from leaving the group due to the threat of predator's attack, phot. J. Żaba • Masajski strażnik ostrzegający turystkę przed oddalaniem się od grupy z uwagi na niebezpieczeństwo zaatakowania przez drapieżniki (Obszar Chroniony Ngorongoro), fot. J. Żaba

The Ngorongoro Crater alone does not make, however, the entire NCA. Owing to tourist infrastructure, the visitors can easily approach also other, undoubtedly unique, attractions of this part of Africa (Fig. 18). Apart from the Ngorongoro Crater, the most important elements of this infrastructure include (Fig. 18): 1 - Safari Lodge on Lake

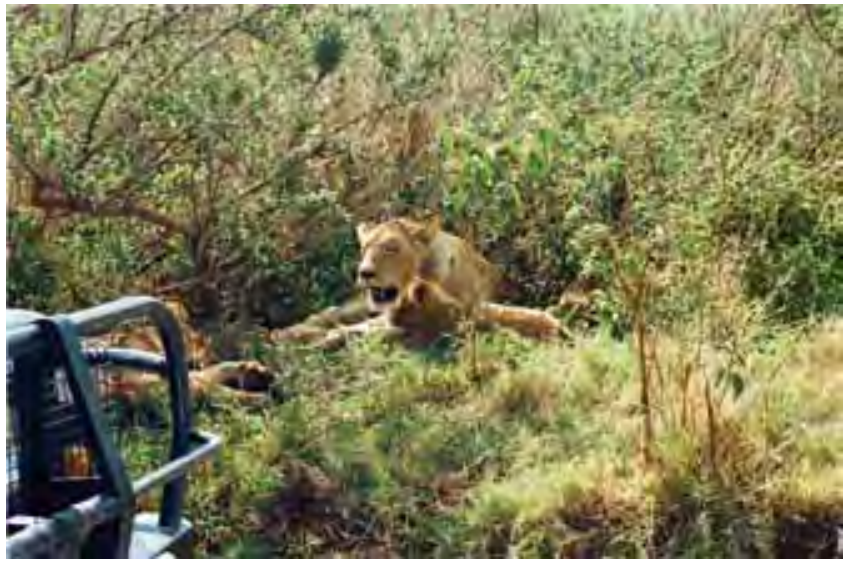

Fig. 6. The largest predator of the Ngorongoro Crater, lion, lying close to the road, phot. J. Żaba $\bullet$ Lew, największy drapieżnik krateru Ngorongoro, wylegujący się w pobliżu drogi, fot. J. Żaba

Ndutu, 2 - interpretation centres (close to Lodoare entrance gate to the NCA - Fig. 7, and the Olduvai Gorge region), 3 - a dozen or so campsites, i.a., close to Lake Ndutu, beneath Empakai and Makarot volcanoes, 4 - a museum housing exhibition concerning human evolution in the Olduvai Gorge region, and 5 - numerous scenic points and rest areas adapted for tourists.

Moreover, in Arusha town situated at the foot of the active Meru volcano, an information centre promoting tourism in Tanzania was opened. Indigenous Maasai community has also been actively engaged in tourist activity with a view to improve their poor living conditions (Figs. 19, 20).

\section{Geotouristic values of the Ngorongoro Conservation Area}

The Ngorongoro Crater attracts crowds of tourists, interested both in animate and inanimate nature, i.e. geotourists. This is not surprising, since this object fulfills all requirements of geotouristic attractions (Żaba, Gaidzik 2010).

There is no doubt that the Ngorongoro Crater allures by its monument form. As the world-largest, not destroyed and unflooded volcanic caldera, it is typified by unique, picturesque landscape that testifies, at the same time, to the character and intensity of geologic processes active in this area in not so distant past (Żaba, Gaidzik 2011b). The observed phenomena raise concern and fear of greatness and inevitability of the forces of nature.

Particularly important from the geo-educational point of view is lithostratigraphic section located on the Lerai road, leading from the bottom of the caldera to its rim (Fig. 10, cf. Żaba, Gaidzik 2011b). The $>300$-m-high wall exposes deposits typical for volcanic areas, represented by alternating "layers" composed of lavas and tuffs that mark successive eruptions of the Ngorongoro volcano. This section, properly described and exposed, will certainly become one of more important geosites within the caldera.

Apart from the Ngorongoro Crater, the NCA also offers other geotouristic attractions. The most important ones include:

The Olduvai or Oldupai Gorge (Fig. 18-A). The gorge bears one of the most famous archaeological and anthropological 


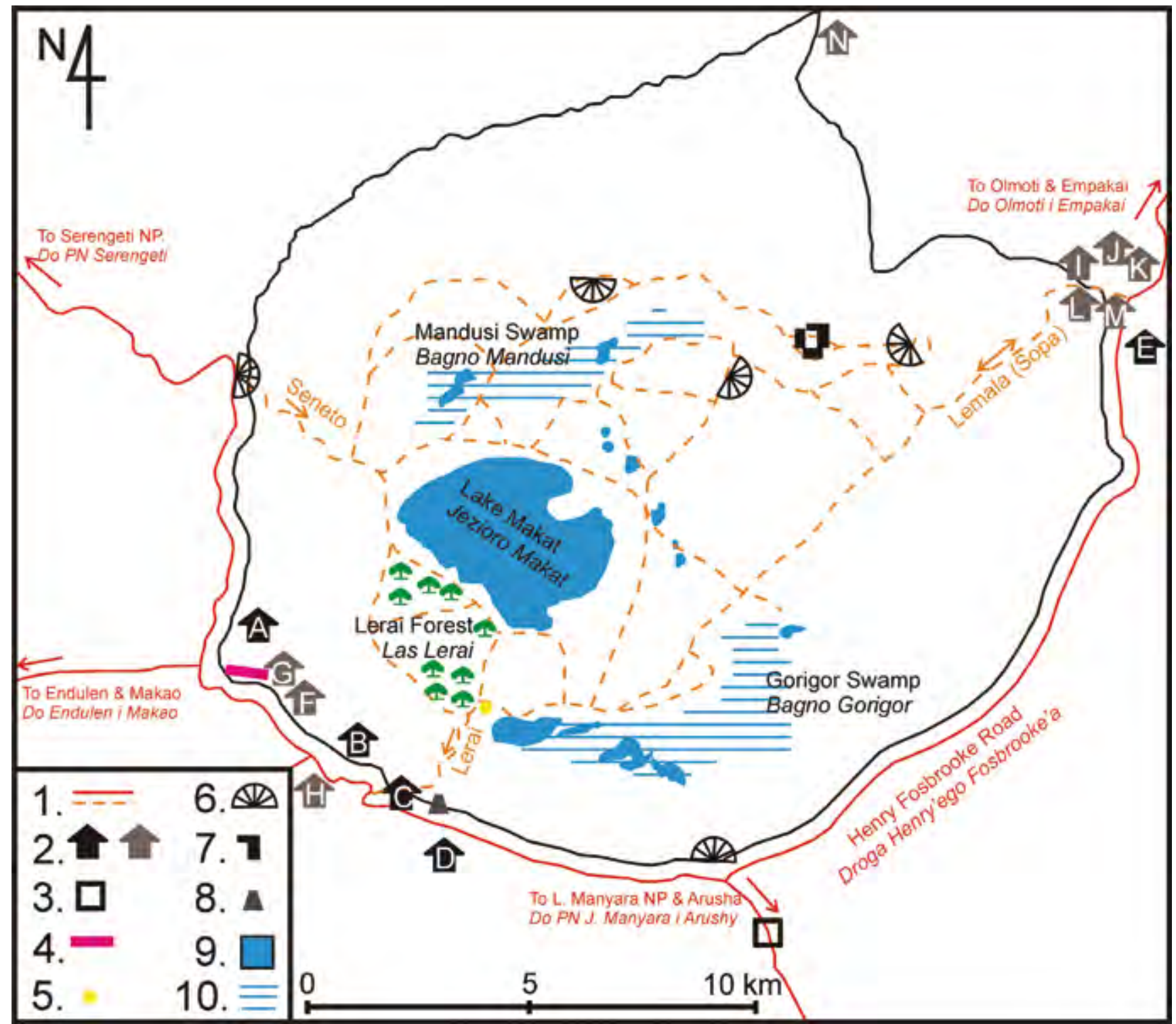

Fig. 7. Geotouristic infrastructure in the Ngorongoro Crater (according to Tombazzi 2003). 1 - main roads, touristic roads in the Ngorongoro Crater, 2 - lodges: A - Serena, B - Crater, C - Wildlife, D - Rhino, E - Sopa; and campsites: F - Simba A, G - Simba B, H - Nyati, I - Tembo A, J - Tembo B, K - Acacia, L - Lemala, M - Lemala Extra, N - Layanai, 3 - Lodoare Gate to NCA, 4 - airstrip, 5 - Lerai picnic site, 6 - scenic points, 7 - ruins of the old, German farm, 8 - Grzimeks' tomb, 9 - lakes, 10 - swamps $\bullet$ Zagospodarowanie geoturystyczne krateru Ngorongoro (według Tombazzi 2003). 1 - drogi dojazdowe, turystyczne drogi w kraterze Ngorongoro, 2 - hotele typu lodge: A - Serena, B - Crater (Kraterowe), C - Wildlife (Dzikiej Przyrody), D - Rhino (Nosorożca), E - Sopa; kempingi: F - Simba A, G - Simba B, H - Nyati, I - Tembo A, J - Tembo B, K - Akacja, L - Lemala, M - Lemala Extra, N - Layanai, 3 - brama Lodoare do NCA, 4 - lądowisko, 5 - miejsce piknikowe Lerai, 6 - punkty widokowe, 7 - ruiny starej, niemieckiej farmy, 8 - grobowiec Grzimeka, 9 - jeziora, 10 - bagna

Fig. 8. Acacia trees growing on the outer slopes of the Ngorongoro Crater. One of the tourist roads within the NCA seen in the background, phot. J. Żaba • Akacje porastające zewnętrzne stoki krateru Ngorongoro. W tle widoczna jedna $\mathrm{z}$ dróg turystycznych w obrębie NCA, fot. J. Żaba

sites where numerous scientifically valuable remains of our ancestors have been found. The area was familiar to archaeologists already at the beginning of the 20th century; however, the most important discoveries were made there in the middle of this century by Louis and Mary Leakey. The most notable. finding from 1959 concerned a hominin Australopithecus boisei (Zinjanthropus), dated to $<1.75 \mathrm{Ma}$.

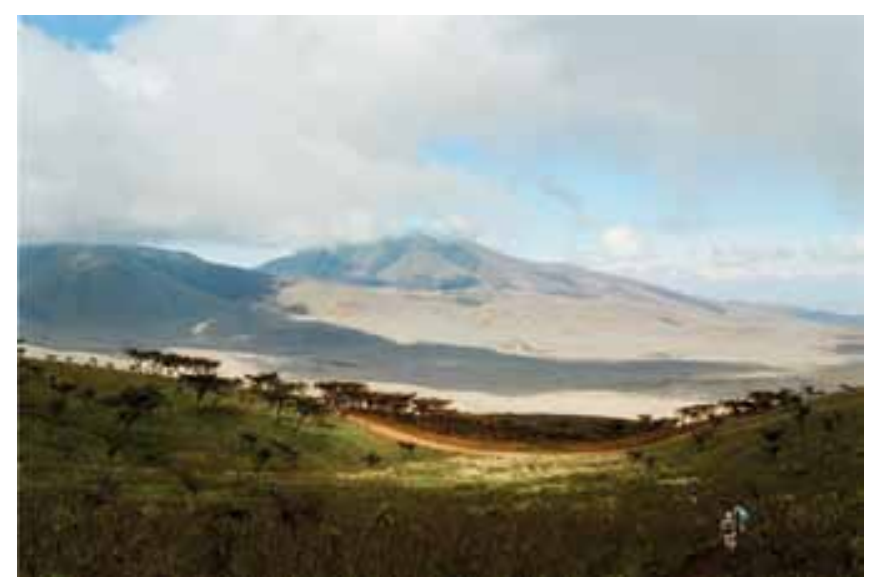




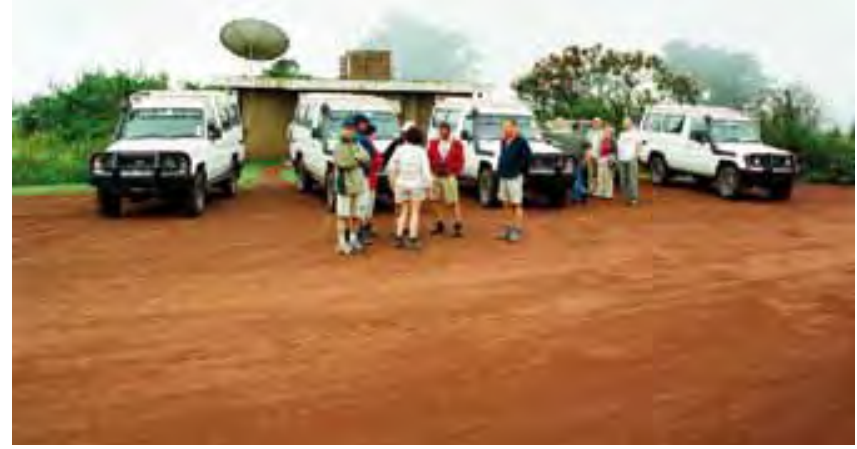

Fig. 9. Cars that are used to travel to the Ngorongoro Crater floor, phot. J. Żaba $\bullet$ Samochody terenowe przygotowane do wyprawy na dno Krateru Ngorongoro, fot. J. Żaba

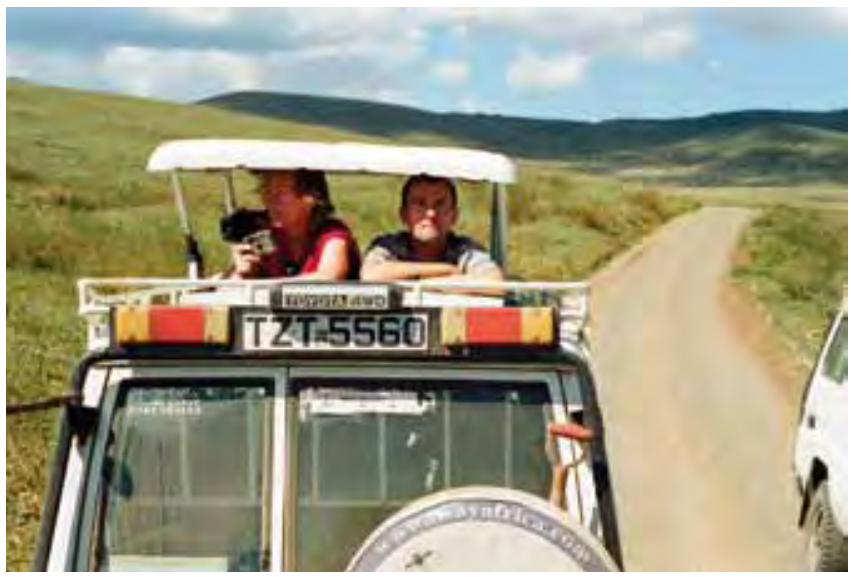

Fig. 11. The only secure way to make photographs on the caldera floor, phot. J. Żaba $\cdot$ Jedyny bezpieczny sposób wykonywania fotografii ma dnie kaldery, fot. J. Żaba

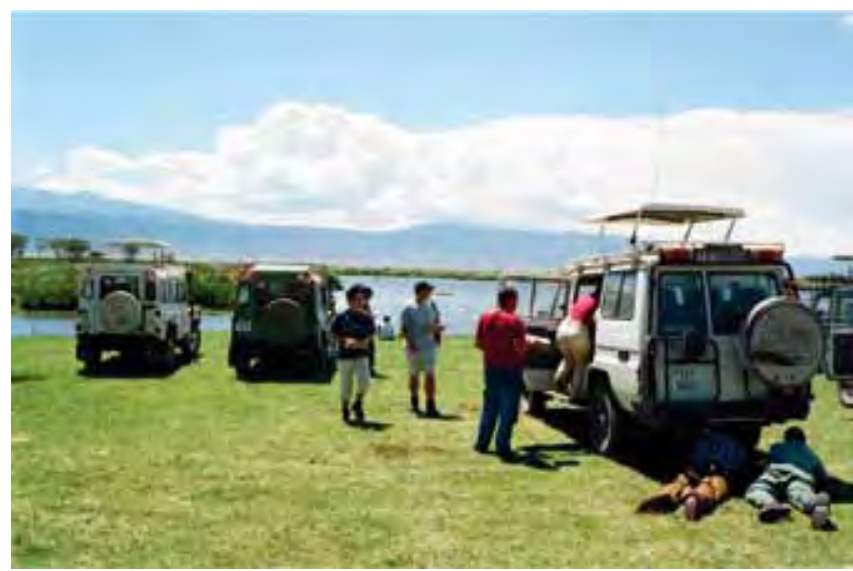

Fig. 13. Due to the protection from huge predatory birds, tourists consume their meals under the car, phot. J. Żaba • Posiłki spożywane pod samochodem z obawy przed atakami drapieżnych ptaków, mogących porwać pożywienie oraz poranić jedzącego, fot. J. Żaba

Also important for the understanding of human evolution were discoveries of remains of Homo habilis and Homo erectus (Leakey L. 1965; Leakey M.D. 1967, 1971, 1976, 1979). Following these spectacular findings, sites located in the Olduvai Gorge have been studied nearly continuously, for a long time nearly exclusively by other members of Leakey

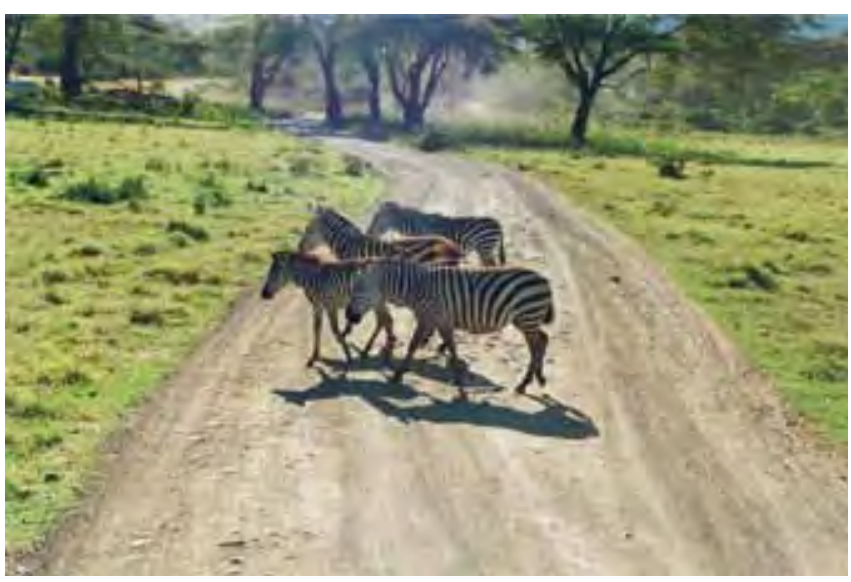

Fig. 10. Zebras passing through the road on the caldera floor, phot. J. Żaba - Zebry przebiegające przez drogę na dnie kaldery, fot. J. Żaba

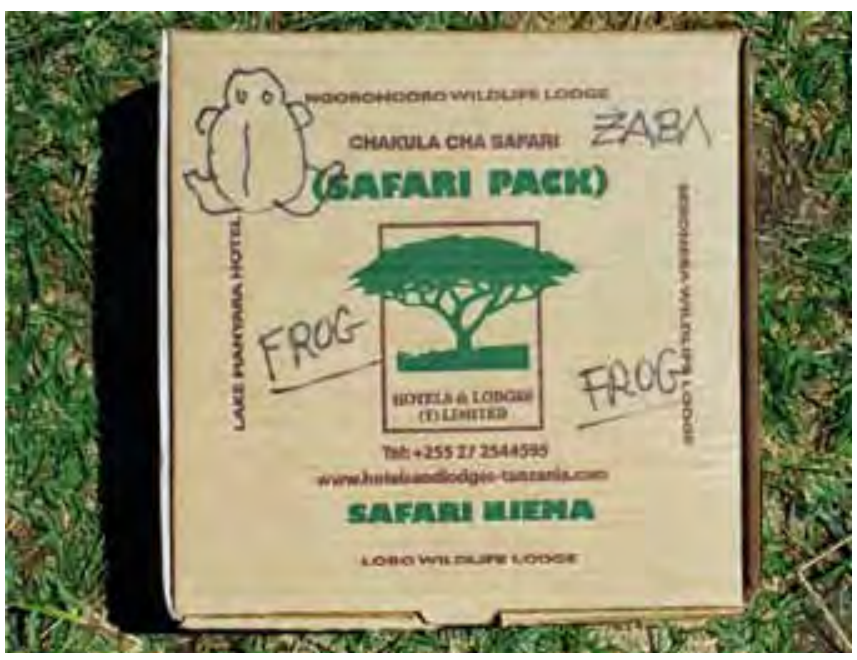

Fig. 12. Meal prepared by the organizers of the excursion within the Ngorongoro Crater, phot. J. Żaba • Porcje żywnościowe przygotowane przez organizatorów wycieczki po obszarze kaldery Ngorongoro, fot. J. Żaba

family. Long-term intensive scientific exploration of the region resulted in finding unusual wealth of artefacts used by our ancestors (Leakey 1967, 1971, 1976; Mora, de la Torre 2005; Diez-Martín et al. 2009), as well as numerous fossilized bones of extinct animals (Leakey 1965). The gorge should be visited together with a hired guard and qualified guide. Of particular interest is a walk down the gorge bottom, due to both unforgetable. views and peculiar feeling of being in the „cradle of humanity”. One should visit as well a museum housing unique exhibits (UNESCO/IUCN 2008). The name of the gorge is also related to the well known ,Olduvai theory", formulated first in 1989 by Richard Duncan and successively modified in the following years (Duncan 1989). According to this theory, industrial civilisation can survive for 100 years only.

The Laetola area (Fig. 18-B). This region is known from famous findings of hominin footprints left in volcanic rocks, discovered in 1972 by Mary Douglas Leakey (Leakey 1979). Most probably, our ancestor attained an already upright position. These footprints can now be admired in a museum located close to the Olduvai Gorge. 
Geotouristic valorization, touristic development and hazard

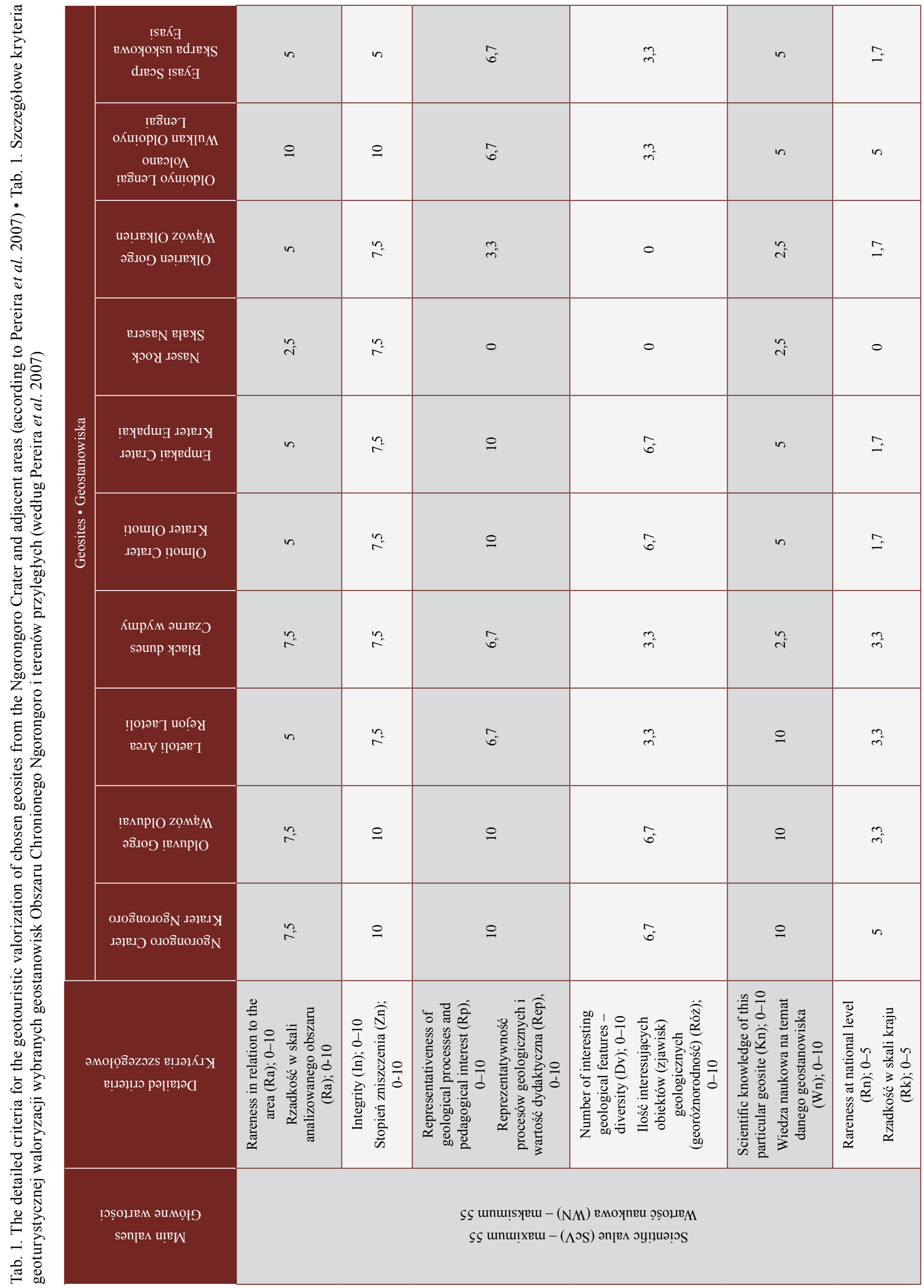




\begin{tabular}{|c|c|c|c|c|c|c|c|c|c|c|}
\hline$\hat{\sim}$ & 으 & $\stackrel{\infty}{m}$ & ț & $a$ & $m^{m}$ & 0 & $\hat{\sigma}$ & L & n & L \\
\hline$\stackrel{n}{i}$ & $\stackrel{2}{\sim}$ & $\underset{\sim}{\infty}$ & $\vec{i}_{i}$ & $\approx$ & 0 & 0 & $\hat{\sigma}$ & $\stackrel{n}{i}$ & 음 & $\stackrel{2}{\rightarrow}$ \\
\hline$\stackrel{n}{i}$ & $\approx$ & $\underset{\sim}{\infty}$ & $\begin{array}{l}0 \\
\infty \\
\infty\end{array}$ & $a$ & $\hat{\sigma}$ & 0 & $m^{m}$ & $\stackrel{n}{\sim}$ & $\stackrel{n}{\sim}$ & 으 \\
\hline 음 & 의 & $\stackrel{\infty}{\sim}$ & $\infty_{\infty}^{\circ}$ & $\stackrel{ح}{2}$ & $\hat{\sigma}^{\circ}$ & $\hat{\sigma}$ & $\stackrel{m}{m}$ & $n$ & $n$ & م \\
\hline$n_{i}$ & $\approx$ & $\stackrel{\infty}{\sim}$ & $\vec{i}$ & $\stackrel{2}{\sim}$ & $\hat{\sigma}$ & $m_{m}^{m}$ & $\stackrel{m}{m}$ & $\because$ & $n$ & ㅇ \\
\hline$n$ & 욱 & $\underset{m}{\infty}$ & $\vec{i}$ & 노 & $m^{m}$ & $m^{m}$ & $m^{m}$ & n & $\stackrel{n}{\sim}$ & 우 \\
\hline$\stackrel{n}{n}$ & 우 & $\stackrel{\infty}{n}$ & $\hat{\varrho}$ & $\approx$ & 0 & 0 & $\hat{\sigma}$ & $n$ & 으 & 几 \\
\hline$\stackrel{2}{\sim}$ & เ & $\stackrel{\infty}{\sim}$ & $\hat{\varrho}$ & $\stackrel{2}{\sim}$ & $\stackrel{m}{m}$ & 의 & $m$ & 우 & $\approx$ & 0 \\
\hline$\stackrel{2}{\sim}$ & $\approx$ & $\stackrel{\infty}{n}$ & $\hat{\circ}$ & $a$ & $\hat{6}$ & 운 & $\stackrel{m}{m}$ & ㅇ & $\stackrel{2}{n}$ & n \\
\hline$\because$ & $\stackrel{2}{2}$ & $\stackrel{2}{2}$ & $\begin{array}{l}0 \\
\infty \\
\infty\end{array}$ & $\stackrel{2}{2}$ & $\hat{\sigma}$ & 의 & $m^{m}$ & 우 & 우 & 우 \\
\hline 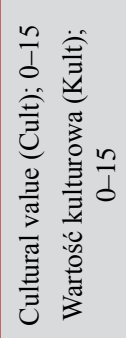 & 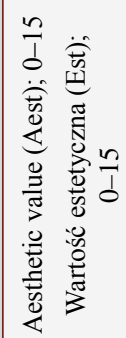 & 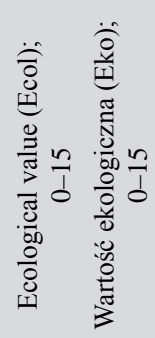 & 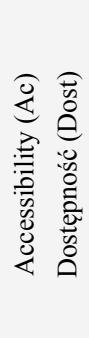 & 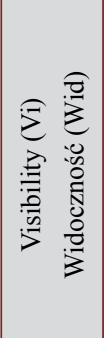 & 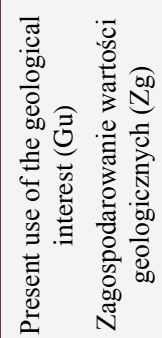 & 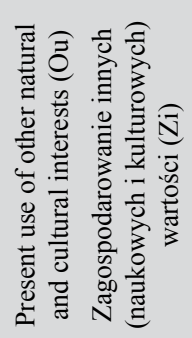 & 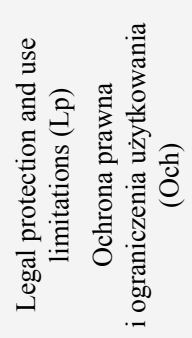 & 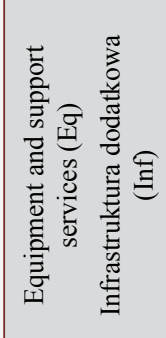 & 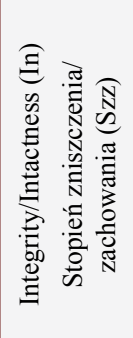 & 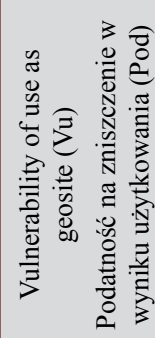 \\
\hline \multicolumn{3}{|c|}{ 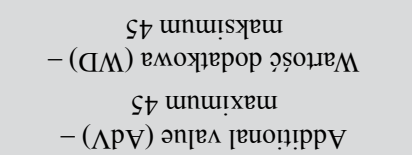 } & & & \multicolumn{4}{|c|}{ 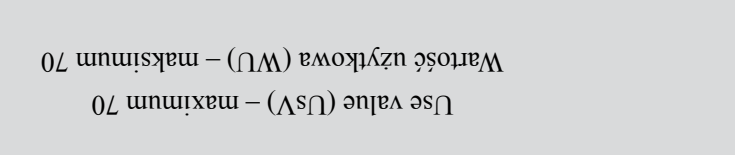 } & \multicolumn{2}{|c|}{ 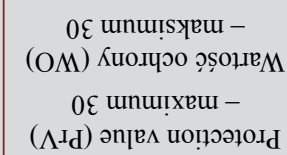 } \\
\hline
\end{tabular}


Geotouristic valorization, touristic development and hazard

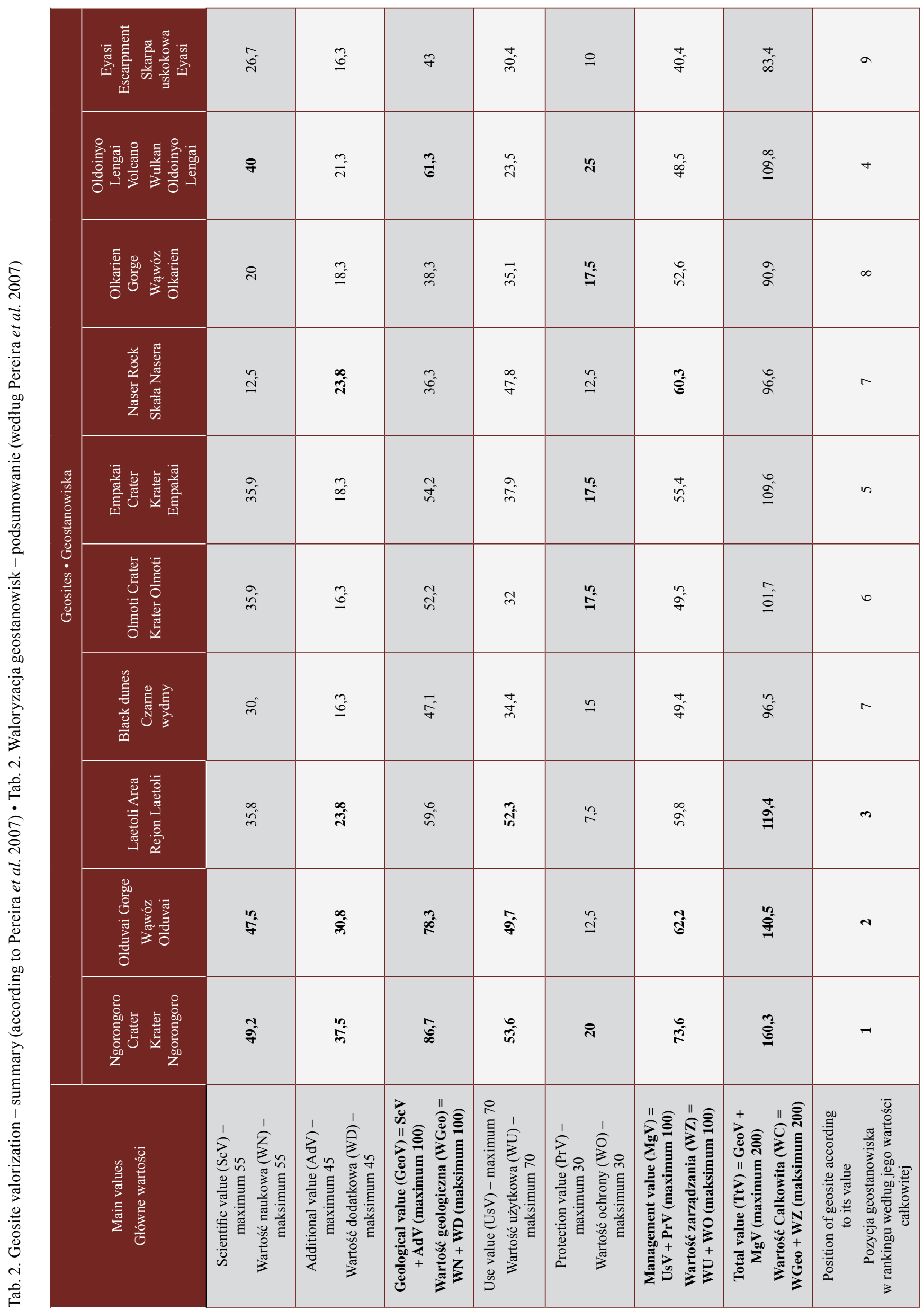




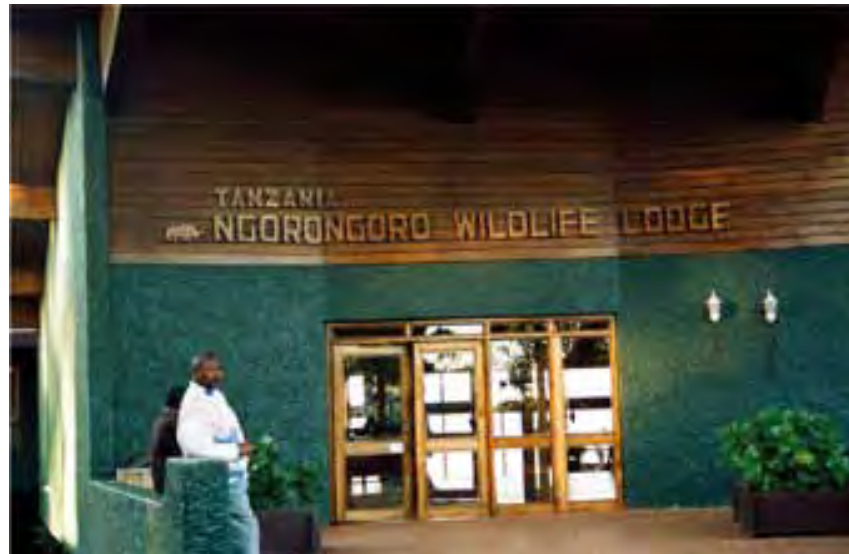

Fig. 14. Wildlife Lodge on the Crater rim (see Fig. 7, C), phot. J. Żaba - Hotel Wildlife (Dzikiej Przyrody) położony na obrzeżeniu krateru (por. fig. 7, C), fot. J. Żaba

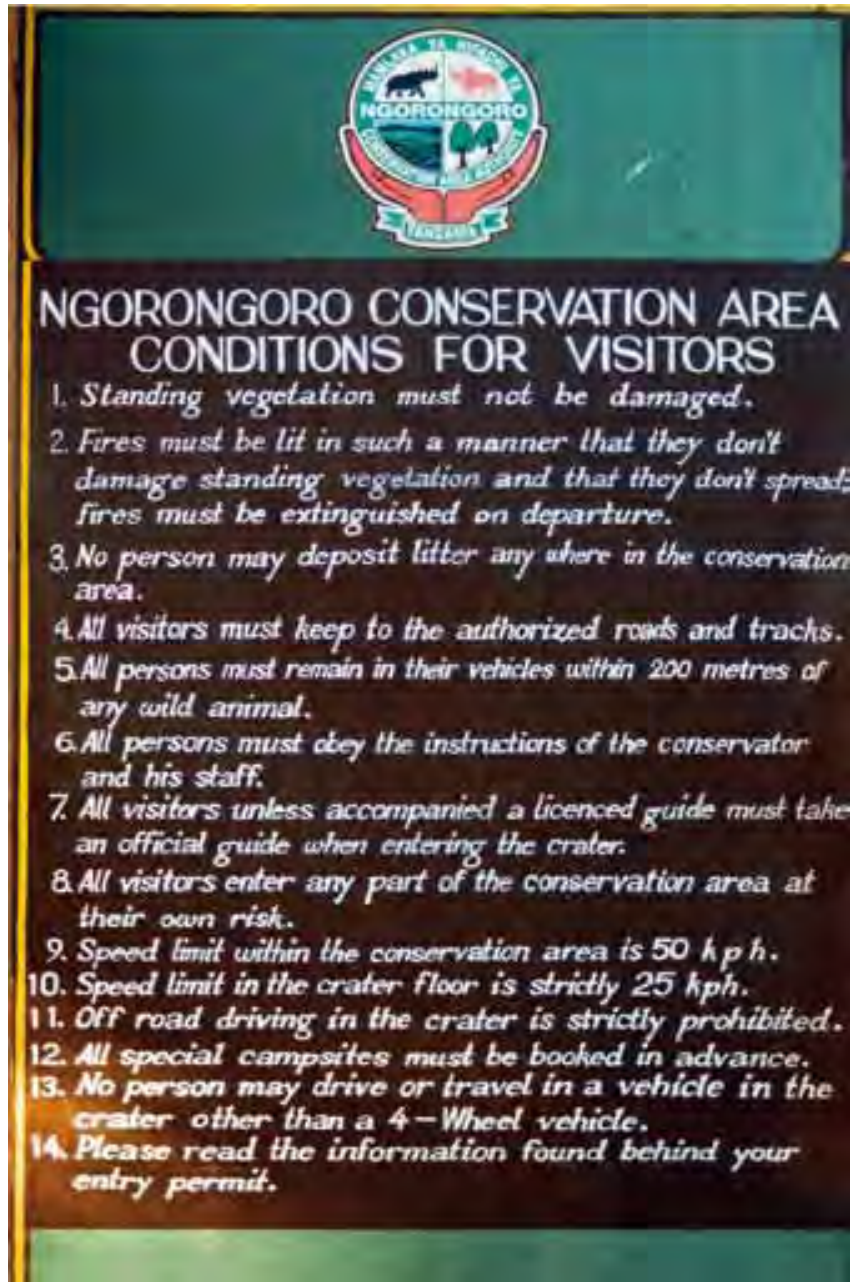

Fig. 16. Regulations for tourists in NCA, phot. J. Żaba • Tablica informacyjna dla turystów odwiedzających NCA, fot. J. Żaba

Black dunes (Fig. 18-C). These are extremely interesting, relatively small dunes composed of black volcanic sand, occurring on plain areas of the Ngorongoro Conservation Area. These landforms are transported by permanent winds with a speed of ca. $18 \mathrm{~m}$ per year (Tombazzi 2003).

The Olmoti Crater (Fig. 18-D; see also Żaba, Gaidzik 2011b). The crater of Olmoti extinct shield volcano, neighbouring the Ngorongoro Crater on the northeast, is extremely

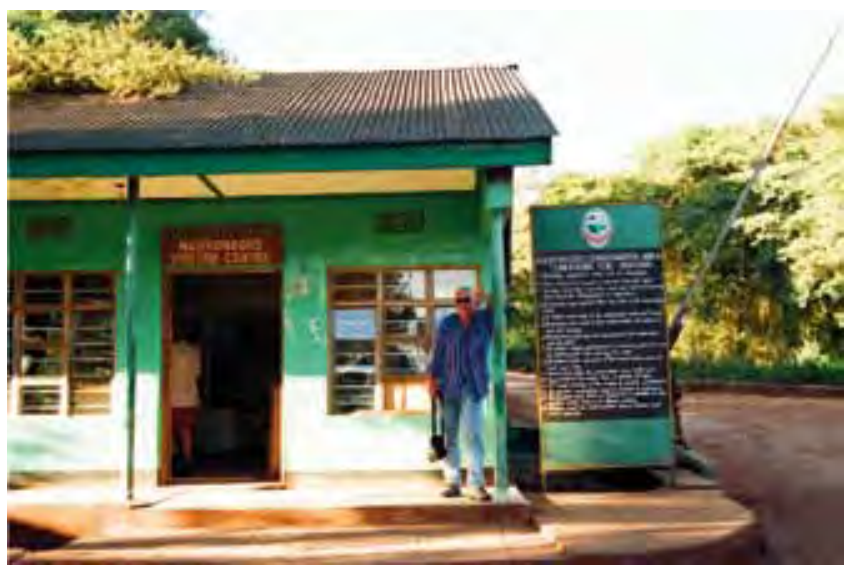

Fig. 15. Jerzy Żaba outside the information point in NCA, phot. J. Żaba - Punkt informacyjny przy bramie wjazdowej na teren NCA, fot. J. Żaba

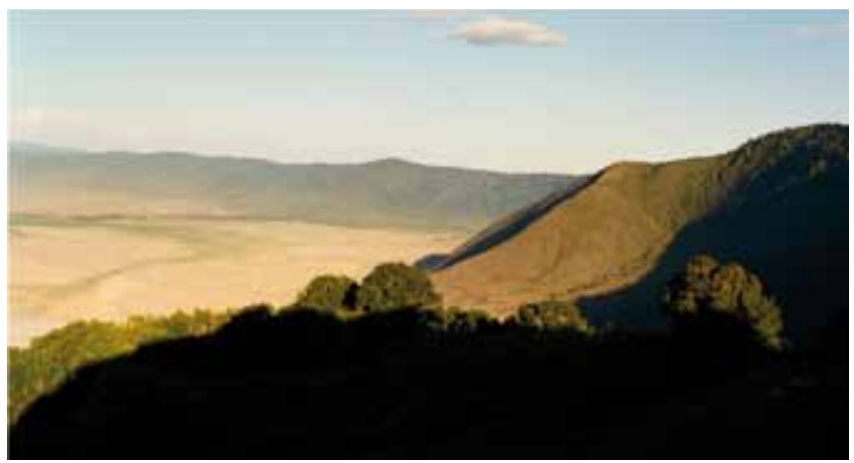

Fig. 17. The Ngorongoro Crater at sunset, phot. J. Żaba • Krater Ngorongoro o zachodzie słońca, fot. J. Żaba

interesting due to a number of reasons. First of all, these are educational values as well aesthetic impressions offered by ascent to the alluring, beautifully preserved volcanic cone. The crater rim provides a breathtaking view to the Ngorongoro caldera with Lake Makat and general panorama of the Crater Highlands. Admiring also is the view of the Olmoti Crater interior, ca. $6.5 \mathrm{~km}$ in diameter. On the way to the top, one passes by magnificent waterfalls of the Munge River cut into volcanic rocks (Tombazzi 2003).

The Empakai Crater (Fig. 18-E; see also Żaba, Gaidzik 2011b). The crater of this extinct shield volcano, ca. $8 \mathrm{~km}$ in diameter, is a minor copy of the Ngorongoro Crater, situated some 1,000 $\mathrm{m}$ higher. This is an ideal trekking destination, which - due to numerous herds of African buffalos - should be visited with a well-armed guard. Climbing the peak of Empakai volcano provides unforgetable views both to the Crater Highlands and crater interior, with breathtaking beauty of Empakai Lake (Tombazzi 2003).

The Naser Rock (Fig. 18-F). The name applies to a huge monolith, ca. $100 \mathrm{~m}$ high, situated in the north-western part of the NCA. It belongs to most frequently visited objects. The place offers magnificent views; it is also a very interesting and important archaeological site (Tombazzi 2003).

The Olkarien Gorge (Fig. 18-G). This gorge, situated in the Doinyoogol mountains, provides geotourists with fascinating views from its precipitous walls. It is a very attractive and highly recommended place. 


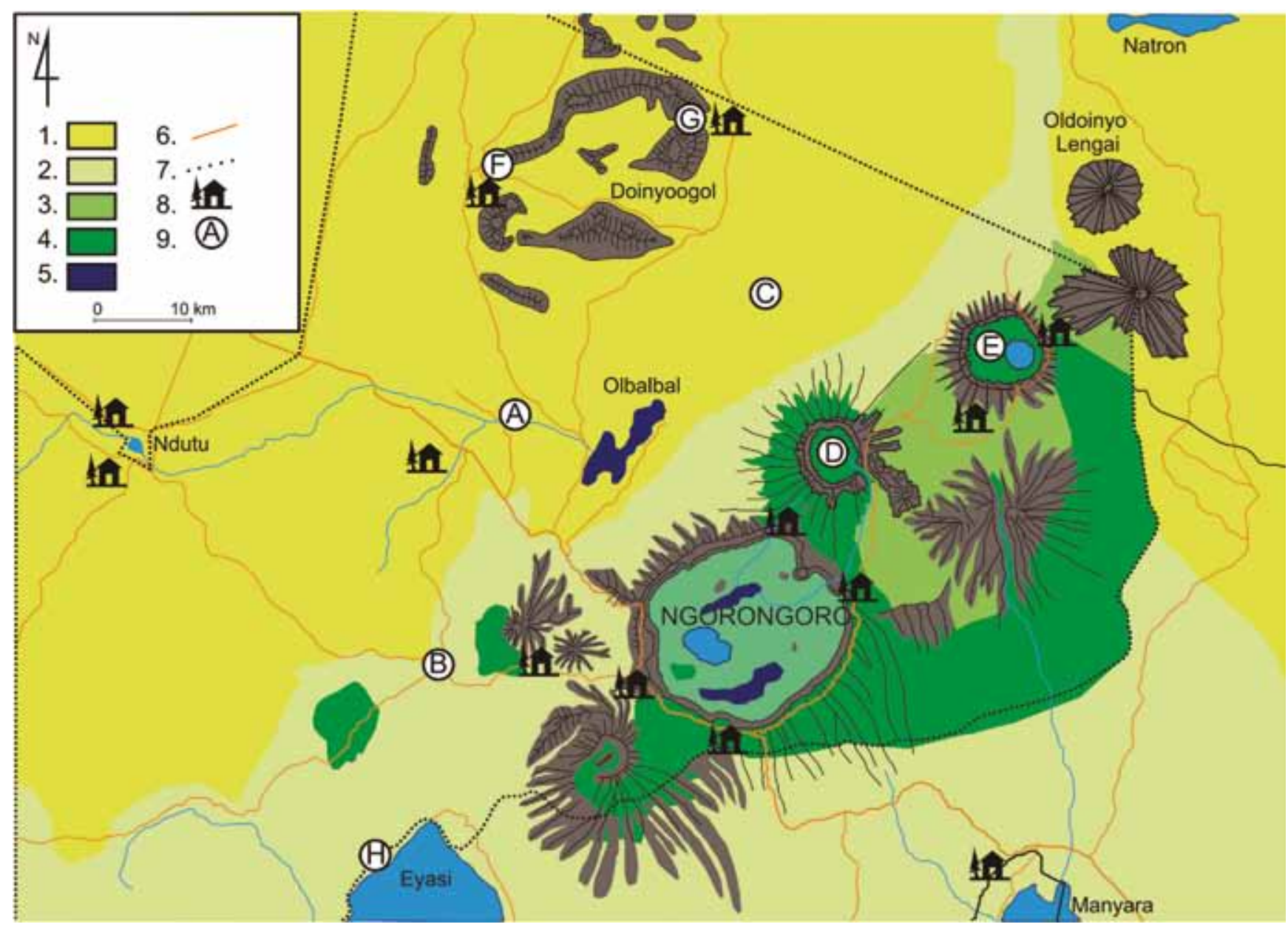

Fig. 18. Geotouristic potential of the Ngorongoro Conservation Area (according to Tombazzi, 2003). 1 - dried grassland, 2 - tall grasses and/or dry woodland of the Crater Highlands, 3 - grassland: plains or depressions of the wetter Highlands and inside the Ngorongoro Crater, 4 - woodland, 5 - swamps, 6 - main roads, 7 - border of the Ngorongoro Conservation Area (NCA), 8 - lodges and campsites, 9 - main geotouristic attractions in this area beside the Ngorongoro Crater (explanations in the text) • Potencjał geoturystyczny Obszaru Chronionego Krater Ngorongoro (według Tombazzi 2003). 1 - suche równiny trawiaste, 2 - tereny Wyżyny Kraterów porośnięte wysoką trawą i/lub suchym lasem, 3 - tereny trawiaste: równiny lub obniżenia Wyżyny Kraterów oraz wnętrze krateru Ngorongoro, 4 - tereny leśne, 5 - bagna, 6 - główne drogi, 7 - granice Obszaru Chronionego Ngorongoro (NCA), 8 - hotele i miejsca kempingowe, 9 - pozostałe, oprócz krateru Ngorongoro, atrakcje geoturystyczne tego obszaru (objaśnienia w tekście)

The Eyasi fault scarp (Fig. 18-H; see also Żaba, Gaidzik 2011b). This fault scarp, well marked in topography and striking along the south-western margin of the Ngorongoro Conservation Area, was formed during the first stage of rifting. It exposes Precambrian metamorphic rocks (Żaba, Gaidzik 2011b). Apart from undoubted geo-indicator values of this structure, magnificent views from its upper edge to the lower situated Lake Eyasi require special attention.

Close to the north-eastern boundary of the Ngorongoro Conservation Area, the cone of active Oldoinyo Lengai volcano (Fig. 18; see also Żaba, Gaidzik 2011b) is to be found. The name of this stratovolcano in Maasai language means "God's Mountain". The name is not accidental, since this is a peculiar volcano: it is the only active volcano on Earth built up of carbonate lava (carbonatite volcano; Dawson 2008). Climbing its peak takes only four hours and is definitely worth of effort. From the top one can admire magnificent views, particularly to the Crater Highlands and the deep Gregory Rift valley (Tombazzi 2003).
In a short distance from the Ngorongoro Crater and NCA, numerous worth-seeing geotouristic attractions are located. The most important of these is the Kilimanjaro (5,895 $\mathrm{m}$ a.s.l.) volcanic massif, the highest peak of Africa and the highest single mountain on Earth. Like the Ngorongoro Crater, this massif is strongly associated with evolution of the Gregory Rift. The volcano began to form ca. 1.8-1.5 Ma, i.e., after cessation of the Ngorongoro volcanic activity, and became extinct only 10 thousands of years ago (Żaba 2005). It is also worth visiting the Arusha National Park, where the highest active volcano of Africa, Meru (4,568 m a.s.l.; Fig. 2; Dawson 2008), is located.

To the southeast, close to the NCA, the Lake Manyara National Park (Fig. 2) is situated, whereas to the west of the Ngorongoro Crater Lake Victoria occurs at an altitude $>1,000 \mathrm{~m}$ a.s.l. Occupying an area of $68,800 \mathrm{sq}$. $\mathrm{km}$, this is the largest lake of Africa. Both lakes are of tectonic origin and have a defined position within the East African Rift System. Owing to undoubted landscape beauty and outstanding natural richness, these objects represent high-ranking geotouristic attractions. 


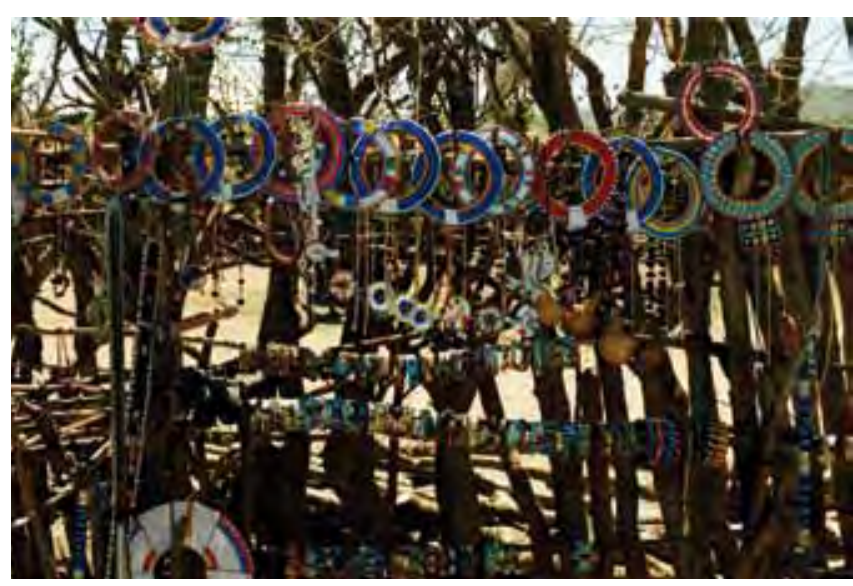

Fig. 19. The Maasai souvenirs for tourists, phot. J. Żaba $\bullet$ Masajskie pamiątki dla turystów, fot. J. Żaba

\section{Geotouristic valorization of the Ngorongoro Conservation Area geosites}

Selected geosites of the Ngorongoro Conservation Area and surrounding terrains were subject to detailed valorization (Tab. 1, 2). To achieve this task, a methodology based on scoring different detail factors influencing on the attractiveness of a given object, clustered into four main categories, was applied (Pereira et al. 2007; Brilha et al. 2009). Besides scientific values, these also include additional, use and protection values. The first two categories can be treated together as a geological value of an object. Application of such a scheme makes it possible to obtain precious data enabling mutual comparison of individual geosites at relative low, as far as ranking of geotouristic values is concerned, level of subjectivity (Pereia et al. 2010).

The Ngorongoro Crater, as the greatest and most important geotouristic attraction of this area, received the highest rank among all geosites considered (Tab. 1, 2). It has, therefore, the highest geotouristic potential in the analyzed area. Nevertheless, this object did not attain the first place in all four, main categories (cf. Tab. 2). It dominates decisively with respect to additional values (Tab. 2), such as: aesthetic, ecological and cultural ones (Tab. 1). Taking into account scientific values, the highest, nearly identical rank, obtained two geosites: the Ngorongoro Crater and Olduvai Gorge (cf. Tab. 2). In the first case, this is related to a peculiar position of this world-largest, not destroyed and unflooded volcanic caldera within the East African Rift System (Żaba, Gaidzik 2011b). Outstanding archaeological findings in the Olduvai Gorge and their importance for understanding human evolution contributed to high ranking of this object with respect to scientific values. Moreover, high rank went also to the only active carbonatite volcano on Earth, i.e. Oldoinyo Lengai (cf. Tab. 2). A particularly low score in this category received the Naser rock, showing mainly aesthetic and some cultural and archaeological values, although of considerably lesser importance compared to the Olduvai Gorge.

Apart from scientific, aesthetic, cultural or ecological values, a geosite should also fulfill the criteria related to tourist traffic potential (use values and protection possibilities). The applied

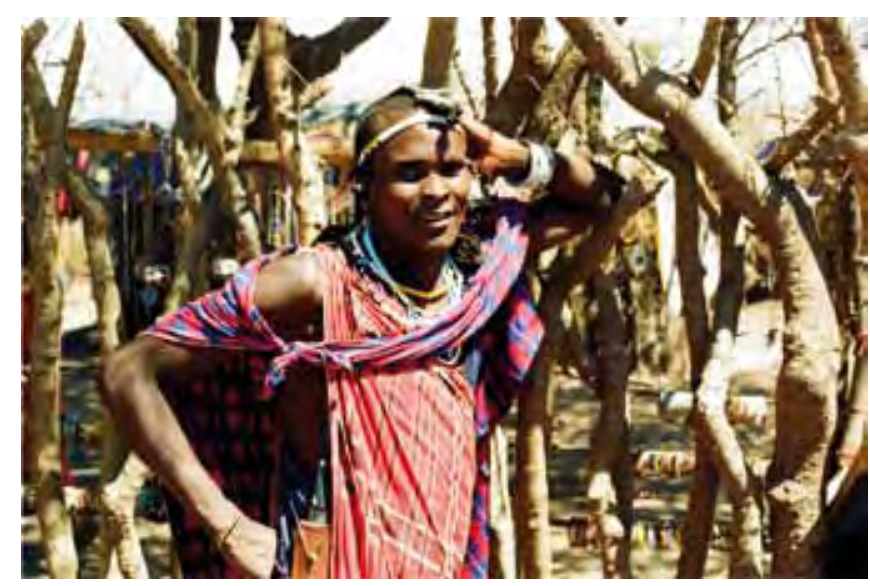

Fig. 20. The Maasai warrior posing for touristic picture, phot. J. Żaba - Wojownik masajski pozujący do zdjęcia, fot. J. Żaba

methodology took into account such indicators, as: accessibility, visibility, reclamation of geological and other values, legal protection, additional infrastructure, integrity, and vulnerability to destruction due to use (Tab. 1). The conducted valorization indicates that the highest use values typify the best known and managed geosites of the Ngorongoro Crater, Olduvai Gorge, and Laetola area (Tab. 2). These objects represent certain "visit cards" of the Ngorongoro Conservation Area; hence, their degree of accessibility, use and protection is highest among all potential geosites considered. Another problem is their vulnerability to destruction. The most resistant are large forms, usually those deprived of outstanding cultural values like, for instance, Oldoinyo Lengai, Olkarien Gorge, or Olmoti and Empakai craters (Tab. 2). The most vulnerable and, thereby, endangered by increased tourist traffic are geosites associated with cultural and ecological values like, e.g., the Olduvai Gorge and Laetola area (Tab. 2).

\section{Hazards}

Despite relatively early initiated activity aiming at protecting natural heritage of the Ngorongoro Crater, the area has been and will certainly be exposed to different types of hazards, both natural and anthropogenic ones. These concern, nearly to the same degree, different elements of animate nature, inanimate natural objects, and cultural values. During the 1984-1989 time span, the Ngorongoro Conservation Area was included in the special UNESCO Global Cultural and Natural Heritage List, the most important values of which are being permanently endangered (UNESCO/IUCN 2008).

Ongoing geological processes associated with the East African Rift System, one of the greatest attractions of the Ngorongoro Crater, could also pose a certain hazard resulting from both seismic and volcanic activity of the area. Up to now, it is impossible to countermeasure these risks and the only NCA activity in this respect consists of monitoring such processes.

Animate nature of the caldera area requires special protection. Numerous animal and plant species living in this area are more or less endangered with extinction. Particularly endangered is, first of all, black rhinoceros (Diceros bicornis), which was included in the Red List of Threatened Species of the International Union for the Conservation of Nature, being 
listed in the category of critically endangered species. Among other species of this list (categories of endangered by extinction and prone to extinction species), one should mention: hippo (Hippopotamus amphibius), African bush elephant (Loxodonta africana), lion (Panthera leo), cheetah (Acinonyx jubatus), African wild dog (Lycaon pictus), and golden cat (Profelis aurata). The most endangered bird species occurring in the crater include, according to the International Union for the Conservation of Nature, lesser kestrel (Falco naumanni) and karamoja apalis (Apalis karamojae; http://www.iucnredlist.org/),

The world of animate and inanimate nature of the Ngorongoro Crater is particularly sensitive to threats posed by both local population and still increasing flow of tourists visiting this place.

\section{Summary}

The Ngorongoro Crater, due to its great, world-unique natural richness as well as magnificently represented and well visible traces of different geological processes (mainly tectonic and volcanogenic ones), deserves to be called the greatest geotouristic attraction of the Gregory Rift and one of the most important attractions of East Africa, and even the entire continent. The constantly increasing number of tourists visiting this region each year testifies to great interest in areas where attractions provided by both animate and inanimate nature are combined with cultural values. Exceptional values of this particular locality were confirmed by its inclusion into the UNESCO World Cultural and Natural Heritage List and protection by other measures as well.

Each year, the Ngorongoro Crater is visited by crowds of tourists whose number, although still growing, is strictly concentrated. It is due to common obligation of hiring guides and guards when visiting the majority of NCA objects. Tourist traffic within the Ngorongoro caldera is only allowed in rented, specially equipped off-road cars, which protect tourists against dangerous animals living in the Crater. The accommodation capacity in this area is strictly determined and closely monitored.

Valorization of the selected nine geosites from the Ngorongoro Conservation Area and its surroundings indicates that the Ngorongoro Crater and Olduvai Gorge have the highest geotouristic potential. All analysed objects are typified by relatively high scientific and aesthetic values. Most of them, however, from those less intensely promoted, obtained lower ranks in the categories of natural protection, tourist infrastructure and use.

Despite strict rules applied in NCA, both the Ngorongoro Crater and inhabiting animal and plant species are constantly subject to different natural and anthropogenic hazards. The latter ones are kept to a minimum by the authorities of the Ngorongoro Conservation Area. Natural hazards result from particular position of this area within the East African Rift System where increased activity of various geological processes is observed. The most hazardous ones include volcanic and seismic activity, strongly associated with rifting that has led to development of great tectonic grabens.

\section{Streszczenie}

Krater Ngorongoro
największą atrakcją geoturystyczną
ryftu Gregory’ego
(północna Tanzania, Afryka)
- waloryzacja geoturystyczna,
zagospodarowanie turystyczne
i zagrożenia

\section{Jerzy Żaba, Krzysztof Gaidzik}

\section{Wstęp}

Krater Ngorongoro pozostawia niezatarte wrażenia u każdego z odwiedzających. Magiczny, iście rajski ogród z tysiącami dziko żyjących zwierząt oraz licznymi, nierzadko bardzo unikalnymi - w tym też endemicznymi - gatunkami roślin przyciąga każdego roku wielbicieli przyrody ożywionej w jej naturalnym, zdającym się być nieskażonym przez człowieka i cywilizację środowisku (Fig. 1; Żaba, Gaidzik 2011a). Monumentalne, majestatyczne szczyty stożków wulkanicznych wznoszących się ponad Wyżyną Kraterów i okalających kalderę Ngorongoro jeszcze bardziej potęgują doznania estetyczne. Niewątpliwe skojarzenia z Zaginionym Światem Sir
Arthura Conan Doyle'a wywołują bardzo strome, a w wielu miejscach pionowe, ściany kaldery wznoszące się na wysokość około 600 metrów ponad jej dno, izolując w ten sposób Ngorongoro od reszty globu.

Jednakże Krater Ngorongoro to nie tylko przyroda ożywiona. Jest to bowiem szczególny przykład - w skali globu - zjawisk i procesów geologicznych bardzo istotnych w rozwoju Ziemi (Żaba, Gaidzik 2011b). Ngorongoro stanowi największą na Ziemi - niezalaną wodą i niezniszczoną - zapadliskową kalderą wulkaniczną, pierwotnie znacznie wyższego niż obecnie (mającego niegdyś prawie 5000 m n.p.m.), rozległego wulkanu tarczowego. Jego aktywność została zapoczątkowana około 3-2 mln lat temu i trwała przez niemalże ćwierć miliona lat. Powstanie i rozwój tej formy były ściśle związane z procesami ryftogenezy zachodzącymi w obrębie ryftu Gregory'ego, będącego jednym z najlepiej poznanych segmentów wschodnioafrykańskiego systemu ryftowego. Stanowi on ramię porzucone, w obrębie którego pomimo widocznych oznak aktywności tektonicznej wraz z towarzyszącymi jej przejawami procesów wulkanicznych nie doszło do ukształtowania się skorupy oceanicznej.

Praca stanowi ostatnią z serii trzech artykułów poświęconych kraterowi Ngorongoro jako największej atrakcji geoturystycznej ryftu Gregory'ego, a najprawdopodobniej także całej Afryki Wschodniej. Dotyczy ona turystycznego zagospodarowania tego rejonu, sposobów ochrony elementów 
przyrody ożywionej i nieożywionej, a także możliwości i zasad działalności człowieka na tym obszarze. Ponadto zawiera informacje na temat zagrożeń zarówno występujących obecnie, jak i mogących się pojawić w niedalekiej przyszłości, związanych z lawinowo rosnącym ruchem turystycznym. Pozostałe dwa artykuły zostały poświęcone uwarunkowaniom przyrodniczym krateru Ngorongoro. W pierwszym z nich zaprezentowano warunki geograficzne tego obszaru (położenie i morfologię terenu, warunki hydrologiczne, klimat, świat przyrody ożywionej oraz miejscową ludność autochtoniczną; Żaba, Gaidzik 2011a), natomiast w drugim - pozycję geologiczną oraz ewolucję Krateru Ngorongoro na tle wschodnioafrykańskiego systemu ryftowego (Żaba, Gaidzik 2011b).

\section{Geokonserwacja}

Stosunkowo wcześnie zauważono pilną potrzebę ochrony unikalności dziedzictwa przyrodniczego i kulturowego krateru Ngorongoro. Już w pierwszej połowie XX wieku zwrócono uwagę na niewątpliwe bogactwo przyrody ożywionej tego obszaru, całkowicie zakazując polowań. W roku 1951 obszar Ngorongoro został włączony w nowo powstały Park Narodowy Serengeti (UNESCO/IUCN 2008). Jednakże kluczowym momentem w historii geokonserwacji tego obszaru był rok 1959, kiedy to utworzono Obszar Chroniony Ngorongoro (Ngorongoro Conservation Area, NCA). Założenia leżące $\mathrm{u}$ podstaw powołania tej formy ochrony nosiły znamiona swoistego eksperymentu. Powstał on bowiem jako pierwszy wielofunkcyjny obszar chroniony w Afryce Wschodniej, mający zapewnić harmonijną koegzystencję świata przyrodniczego z lokalną społecznością Masajów (Estes et al. 2006). Jednakże zbyt intensywny wzrost liczby ludności autochtonicznej oraz związanej z tym działalności agrokulturowej i pasterskiej (stada bydła liczące dziesiątki tysięcy sztuk) stanowił coraz większe zagrożenie dla niemal wszystkich istotnych elementów przyrodniczych krateru. Sytuacja ta doprowadziła do radykalnej zmiany w sposobie zarządzania tymi terenami przez władze Obszaru Chronionego Ngorongoro (Ngorongoro Conservation Area Authority, NCAA). W roku 1975 ludność masajską wysiedlono poza obręb krateru i zakazano wszelkiej działalności związanej z uprawą roślin w jego obrębie. Od tego czasu Masajowie żyją nadal w obrębie NCA, jednakże w samej kalderze Ngorongoro nie ma obecnie żadnych stałych mieszkańców (UNESCO/IUCN 2008).

Obszar Chroniony Ngorongoro zajmuje powierzchnię $8292 \mathrm{~km}^{2}$, co stanowi niecały $1 \%$ powierzchni Tanzanii, jednakże jest to teren o powierzchni ponad trzykrotnie większej niż na przykład państwa Luksemburg. Oprócz samej kaldery, która jest bez wątpienia najważniejszym obiektem w NCA, obejmuje on również inne wygasłe wulkany tarczowe ryftu Gregory’ego znajdujące się na Wyżynie Kraterów takie jak Oldeani, Olmoti, Loolmalasin, Empakai, Kerimasi, Makarot (por. Żaba, Gaidzik 2011b), a także wzgórza Doinyoogol i wąwóz Olduvai. Ponadto tuż przy granicy z NCA znajduje się jedyny na Ziemi czynny wulkan karbonatytowy Oldoinyo Lengai. Obszar Chroniony Ngorongoro zajmuje szczególne miejsce w północnej Tanzanii, sąsiadując $\mathrm{z}$ wieloma terenami o różnej randze ochrony (Fig. 2). Graniczy on: 1 - od zachodu z Parkiem Narodowym Serengeti (Serengeti National Park) oraz rezerwatem przyrody
Maswa (Maswa Game Reserve), 2 - od południowego zachodu z obszarem chronionym Makao (Makao Game Controled Area), 3 - od południa poprzez jezioro Eyasi z obszarem chronionym Mang'ola (Mang'ola Game Controlled Area), 4 - od wschodu z obszarami chronionymi: Mto-WaMbu (Mto-Wa-Mbu Game Controlled Area) i jeziora Natron (Lake Natron Game Controlled Area), 5 - od północy z obszarem chronionym Loliondo (Loliondo Game Controlled Area).

W stosunkowo niewielkiej odległości na wschód i południowy-wschód od NCA znajdują się parki narodowe: jeziora Manyara, Arusha (obejmujący najwyższy czynny wulkan Afryki - Meru) oraz Kilimandżaro, w obrębie którego znajduje się najwyższa góra Afryki (Fig. 2).

Świadectwem bogactwa przyrodniczego krateru Ngorongoro jest między innymi uznanie tego obszaru w 1981 roku za Rezerwat Biosfery w ramach programu UNESCO Człowiek i Biosfera (UNESCO/IUCN 2008) oraz za światowy Obszar Ptaków Endemicznych (Fishpool, Evans, red. 2001). Ponadto NCA znajduje się w gronie 200 Światowych Ekoregionów Słodkiej Wody WWF (WWF Global 200 Freshwater Eco-region; UNESCO/IUCN 2008).

W roku 1978 krater Ngorongoro został wpisany na Listę Światowego Dziedzictwa Kulturowego i Przyrodniczego UNESCO, jako obiekt o charakterze przyrodniczym (http:// whc.unesco.org/en/). W ten sposób doceniono zarówno jego niewątpliwe bogactwo przyrody ożywionej, jak i nieożywionej. Podkreślono też szczególne znaczenie procesów ryftogenezy i związaną z nimi aktywnością wulkaniczną. $Z$ uwagi na rewelacyjne odkrycia archeologiczne dotyczące ewolucji człowieka dokonane w ostatnich latach w obrębie wąwozu Olduvai i rejonu Laetoli, Komitet Światowego Dziedzictwa uznał i dopisał 31 lipca 2010 roku znaczenie aspektów kulturowych dla Obszaru Chronionego Ngorongoro. Obecnie NCA jest kwalifikowane na liście UNESCO jako obiekt mieszany, wpisany z uwagi na pięć - spośród dziesięciu kryteriów (jedno kryterium kulturowe - nr IV oraz wszystkie możliwe kryteria przyrodnicze - nr VII, VIII, IX i X; UNESCO 2005). Według tych kryteriów, sformułowanych przez Komitet Światowego Dziedzictwa UNESCO, Obszar Chroniony Ngorongoro spełnia następujące warunki: kryterium IV - przedstawia szczególny przykład typu budowli, zespotu architektonicznego lub technologicznego albo krajobrazu ilustrujacego ważny etap (lub etapy) $w$ historii ludzkości, kryterium VII - obejmuje wyjatkowe zjawiska przyrodnicze lub tereny szczególnego naturalnego piękna i o estetycznym znaczeniu, kryterium VIII - przedstawia szczególne świadectwo ważnych etapów $w$ historii planety, zawierajace ślady dawnego życia, istotnych toczacych się procesów geologicznych tworzących formy uksztattowania terenu lub istotne formacje geomorficzne lub fizjograficzne, kryterium IX - przedstawia szczególny przykład toczacych się procesów ekologicznych i biologicznych, istotnych dla ewolucji i rozwoju ladowych, słodkowodnych, przybrzeżnych i morskich ekosystemów lub społeczności roślin i zwierząt oraz kryterium X - obejmuje najważniejsze środowiska przyrodnicze do ochrony różnorodności form życia, łacznie z zagrożonymi gatunkami o uniwersalnej wartości z punktu widzenia nauki i konserwacji przyrody. 


\section{Ruch turystyczny}

Krater Ngorongoro z uwagi na bogactwo i różnorodność świata przyrodniczego i kulturowego oraz obecność na Liście Światowego Dziedzictwa Kulturowego i Przyrodniczego UNESCO stanowi jedną z najczęściej odwiedzanych atrakcji turystycznych Tanzanii. Prawie 25\% wszystkich turystów odwiedzających północną Tanzanię zwiedza również Obszar Chroniony Ngorongoro. W ciągu ostatnich trzech dekad liczba turystów wzrosła tam ponad dziesięciokrotnie - $\mathrm{z}$ poziomu około 35 tysięcy w 1983 roku do prawie 360 tysięcy w 2006 roku (w tym ponad 250 tysięcy stanowili turyści zagraniczni). Władze NCA planowały do roku 2010 zwiększyć liczbę turystów do jednego miliona (UNESCO/IUCN 2007).

Wzrost liczby turystów odwiedzających krater Ngorongoro nie jest przypadkowy. Jest on przede wszystkim efektem intensywnej działalności władz Obszaru Chronionego Ngorongoro (NCAA), które stale rozwijają infrastrukturę turystyczną w tym rejonie. Bardzo rzetelnie i przejrzyście jest prowadzona oficjalna strona internetowa Obszaru Chronionego Ngorongoro (Fig. 3; http://www.ngorongorocrater.org/ welcome.html). Z zawartych na niej informacji potencjalni turyści mogą się dowiedzieć co warto zwiedzić oraz jakie są przepisy prawne i organizacyjne w obrębie NCA. Ponadto mogą oni uzyskać wszelkie dane na temat: kosztów pobytu i warunków na miejscu, możliwości wynajęcia samochodu oraz przewodnika, a także tego, co należy ze sobą zabrać, udając się do krateru. Jeśli te informacje nie są wystarczające na stronie tej można także zadawać własne, bardziej lub mniej szczegółowe pytania. Niezwykle istotna jest wiadomość, iż zarówno do krateru Ngorongoro, jak i wąwozu Olduvai można się udać tylko i wyłącznie w asyście licencjonowanego przewodnika. Turyści odwiedzający NCA powinni również być ochraniani przez przeszkolonych i uzbrojonych strażników, głównie z uwagi na obawę przed atakami drapieżnych ssaków żyjących na tym obszarze (Fig. 4, 5, 6).

Na dno kaldery prowadzą trzy drogi (Fig. 7, 8) wytyczone i przystosowane na potrzeby ruchu turystycznego:

- Seneto - będąca wyłącznie drogą zjazdową;

- Lerai - służąca tylko jako droga wyjazdowa;

- Lemala (Sopa) - droga, którą możliwe jest poruszanie się w dwu kierunkach (zarówno w dół, jak i w górę).

$\mathrm{Na}$ dnie kaldery wytyczono wiele wzajemnie krzyżujących się dróg, które umożliwiają turystom dotarcie do wszystkich interesujących i wartych zobaczenia miejsc (Fig. 7). Można poruszać się tam wyłącznie wynajętym, specjalnie do tego przystosowanym samochodem (Fig. 9). Zapewnia on ochronę przed licznymi niebezpiecznymi zwierzętami żyjącymi w kalderze (Fig. 6, 10), jednocześnie umożliwiając bezpieczne spożywanie posiłków oraz fotografowanie (Fig. 11, 12, 13).

Na krawędzi kaldery znajduje się pięć hoteli (lodge - Fig. 7): Serena Lodge, Crater Lodge (Hotel Kraterowy), Rhino Lodge (Hotel Nosorożca), Wildlife Lodge (Hotel Dzikiej Przyrody; Fig. 14) i Sopa Lodge. Obiekty te oferują w sumie ponad 500 miejsc noclegowych (UNESCO 2005). Ponadto w obrębie korony kaldery położonych jest kilka specjalnie wyznaczonych miejsc kempingowych (campsites; Fig. 7). Na terenie NCA znajdują się także punkty informacji turystycznej (Fig. 15, 16). Dla turystów zostały ponadto wyznaczone i przygotowane specjalne punkty widokowe, z których można podziwiać imponującą panoramę „Arki Afryki” (Fig. 7, 17).

Jednakże Obszar Chroniony Ngorongoro to nie tylko sam Krater. Odwiedzający ten obszar, dzięki infrastrukturze turystycznej rozwiniętej na całym terenie NCA, mogą swobodnie dotrzeć również do innych, niewątpliwie wyjątkowych, atrakcji tej części Afryki (Fig. 18). Poza kraterem Ngorongoro do bardziej istotnych elementów tej infrastruktury należą (Fig. 18): 1 - Safari Lodge (Hotel Safari) nad jeziorem Ndutu, 2 - centra interpretacyjne (w pobliżu bramy wjazdowej Lodoare do NCA - Fig. 7 oraz w rejonie wąwozu Olduvai), 3 - kilkanaście miejsc kempingowych (campsites), m.in.: w rejonie jeziora Ndutu, pod wulkanami: Empakai oraz Makarot, 4 - muzeum z ekspozycją dotyczącą rozwoju ludzkości w rejonie wąwozu Olduvai, 5 - wiele punktów widokowych oraz miejsc wypoczynkowych przygotowanych dla turystów.

Ponadto w mieście Arusha, leżącym u podnóża czynnego wulkanu Meru, otwarto w 2002 roku centrum informacyjne mające promować turystykę w Tanzanii. Także autochtoniczna ludność masajska zaangażowała się bardzo aktywnie w działalność turystyczną, widząc w tym szansę wyjścia z biedy (Fig. 19, 20).

\section{Walory geoturystyczne Obszaru Chronionego Ngorongoro}

Krater Ngorongoro przyciąga rzesze turystów zarówno tych ukierunkowanych na przyrodę ożywioną, jak i zainteresowanych tzw. przyrodą nieożywioną, czyli geoturystów. Trudno się temu dziwić, gdyż obiekt ten spełnia wszystkie wymagania stawiane atrakcjom geoturystycznym (Żaba, Gaidzik 2011b).

Niewątpliwie krater Ngorongoro urzeka swą monumentalną formą. Jako największa niezniszczona i niezalana wodą kaldera wulkaniczna Ziemi tworzy niepowtarzalny, malowniczy krajobraz. Jednocześnie świadczy o charakterze oraz intensywności procesów geologicznych, które w niedalekiej przeszłości zachodziły na tym obszarze (Żaba, Gaidzik 2011b). Obserwowane zjawiska budzą też niepokój i lęk przed ogromem oraz nieuchronnością sił przyrody.

Szczególnie interesujący z geoedukacyjnego punktu widzenia jest profil stratygraficzny znajdujący się przy drodze Lerai prowadzącej z dna kaldery ku jej koronie (por. Żaba, Gaidzik 2010b; Fig. 7). Na ścianie o wysokości ponad $300 \mathrm{~m}$ odsłaniają się tam utwory typowe dla obszarów wulkanicznych, reprezentowane przez naprzemianległe „warstwy” zbudowane z law oraz tufów, będące śladem kolejnych erupcji wulkanu Ngorongoro. Profil ten - prawidłowo opisany i wyeksponowany - z pewnością ma szansę stać się jednym z ważniejszych geostanowisk w obrębie kaldery.

Oprócz krateru Ngorongoro na obszarze NCA znajduje się wiele innych atrakcji geoturystycznych. Do najważniejszych z nich należą:

Wąwóz Olduvai lub Oldupai (Fig. 18-A). W wąwozie tym znajduje się jedno z najsłynniejszych stanowisk archeologicznych i antropogenicznych, w obrębie którego natrafiono na wiele bardzo wartościowych pod względem naukowym szczątków naszych praprzodków. Pomimo iż rejon ten był znany archeologom już od początku XX wieku, najbardziej znaczące odkrycia zostały dokonane w połowie tego stulecia 
przez małżeństwo Louisa i Mary Leakey’ów. Do najważniejszych należą znaleziska z 1959 roku hominida Australopithecus boisei (Zinjanthropus) sprzed 1,75 mln lat temu. Także bardzo ważne dla zrozumienia ewolucji rodzaju ludzkiego są odkrycia szczątków hominida Homo habilis i Homo erectus (Leakey L. 1965; Leakey M.D. 1967, 1971, 1976, 1979). Po tych spektakularnych odkryciach w obrębie stanowisk znajdujących się w wąwozie Olduvai prowadzi się niemalże nieprzerwane prace badawcze, przez długi okres czasu prawie wyłącznie przez kolejnych członków rodziny Leakeyów. W wyniku tych długotrwałych i intensywnych badań w rejonie tym natrafiono na niezwykłe bogactwo narzędzi i przedmiotów użytkowanych przez naszych praprzodków (Leakey 1967, 1971, 1976, Mora, de la Torre, 2005, Diez-Martín et al. 2009), a także wiele skamieniałych kości wymarłych już zwierząt (Leakey 1965). Do wąwozu należy udać się wraz z wynajętym strażnikiem oraz licencjonowanym przewodnikiem. Szczególnie interesujące, z uwagi na niezapomniane widoki oraz poczucie szczególnej atmosfery „,kolebki ludzkości”, jest przejście dnem wąwozu. Znajduje się tam też warte zwiedzenia muzeum, w którym zgromadzono unikatowe eksponaty (UNESCO/IUCN 2008). Z nazwą wąwozu wiąże się również znana teoria Olduvai, sformułowana po raz pierwszy w 1989 roku przez Richarda Duncana, a w kolejnych latach udoskonalana (Duncan 1989). Zgodnie z nią cywilizacja industrialna może trwać co najwyżej 100 lat.

Rejon Laetoli (Fig. 18-B). W rejonie tym znaleziono, bardzo dobrze zachowane w skałach wulkanicznych, odciski stóp hominida sprzed 3,6 milionów lat. Tego niezmiernie ważnego odkrycia dokonała w 1972 roku Mary Douglas Leakey (Leakey 1979). Najprawdopodobniej ten nasz praprzodek poruszał się już w postaci wyprostowanej. Obecnie ślady te można podziwiać w muzeum znajdującym się w pobliżu wąwozu Olduvai.

Czarne wydmy (Fig. 18-C). Są to niezmiernie interesujące, stosunkowo niewielkie wydmy zbudowane z czarnego piasku wulkanicznego. Występują one na terenach równinnych Obszaru Chronionego Ngorongoro. Formy te są przemieszczane w tempie około $18 \mathrm{~m} /$ rok przez stałe wiatry (Tombazzi 2003).

Krater Olmoti (Fig. 18-D; por. też Żaba, Gaidzik 2011b). Krater wygasłego wulkanu tarczowego Olmoti, sąsiadujący od północnego wschodu z kraterem Ngorongoro, jest niezwykle interesujący z kilku powodów. Przede wszystkim są to walory edukacyjne, a także doznania estetyczne podczas wspinaczki na urokliwy, pięknie zachowany stożek wulkaniczny. Z korony krateru roztacza się zapierający dech w piersiach widok na kalderę Ngorongoro wraz z jeziorem Makat oraz ogólną panoramę Wyżyny Kraterów. Godny podziwu jest również widok wnętrza krateru Olmoti, którego średnica wynosi około $6,5 \mathrm{~km}$. Podczas drogi na szczyt wulkanu Olmoti mija się wspaniałe wodospady na rzece Munge utworzone w obrębie skał wulkanicznych (Tombazzi 2003).

Krater Empakai (Fig. 18-E; por. też Żaba, Gaidzik, 2011b). Krater tego wygasłego wulkanu tarczowego, o średnicy prawie $8 \mathrm{~km}$, jest - położoną $1000 \mathrm{~m}$ wyżej - miniaturą krateru Ngorongoro. Obiekt ten stanowi idealny cel pieszych wędrówek, które $\mathrm{z}$ uwagi na znajdujące się w tym rejonie liczne stada bawołów afrykańskich, należy odbyć z dobrze uzbro- jonym strażnikiem. Dotarcie na szczyt wulkanu Empakai zapewnia niezapomniane widoki zarówno na Wyżynę Kraterów, jak i wnętrze krateru, z urzekającym swym pięknem jeziorem Empakai (Tombazzi 2003).

Skała Nasera (Fig. 18-F). Nazwą tą jest określany potężny monolit o wysokości około $100 \mathrm{~m}$, leżący w północnozachodniej części Obszaru Chronionego Ngorongoro. Stanowi on jeden z częściej odwiedzanych przez turystów obiektów. Jest to miejsce odznaczające się wspaniałymi widokami, a także interesujące i bardzo ważne stanowisko archeologiczne (Tombazzi 2003).

Wąwóz Olkarien (Fig. 18-G). Wąwóz ten, znajdujący się w obrębie Doinyoogol, zapewnia geoturystom fascynujące widoki, które roztaczają się z jego stromych ścian. Jest to miejsce bardzo atrakcyjne i godne polecenia.

Skarpa uskokowa Eyasi (Fig. 18-H; por. też Żaba, Gaidzik 2011b). Ta bardzo wyraźnie zaznaczająca się w morfologii skarpa uskokowa przebiega wzdłuż południowo-zachodniej granicy Obszaru Chronionego Ngorongoro. Ukształtowała się ona podczas pierwszego etapu ryftogenezy. W jej obrębie odsłaniają się prekambryjskie skały metamorficzne (Żaba, Gaidzik 2011b). Poza niewątpliwymi walorami geoedykacyjnymi tej struktury szczególnie godne uwagi są wspaniałe widoki, które rozciągają się z jej górnej krawędzi na położone poniżej jezioro Eyasi.

Tuż przy północno-wschodniej granicy Obszaru Chronionego Ngorongoro znajduje się stożek czynnego wulkanu Oldoinyo Lengai (Fig. 18; por. też Żaba, Gaidzik 2011b). Nazwa tego stratowulkanu w języku Masajów oznacza „Górę Boga”. I jak się okazuje nie jest ona przypadkowa, gdyż jest to wulkan szczególny. Stanowi on jedyny na kuli ziemskiej aktywny wulkan o lawie węglanowej (wulkan karbonatytowy; Dawson 2008). Wspinaczka na jego szczyt zajmuje zaledwie cztery godziny i jest zdecydowanie warta wysiłku. Roztaczają się stamtąd wspaniałe widoki, zwłaszcza na Wyżynę Kraterów i głęboką dolinę ryftu Gregory'ego (Tombazzi 2003).

W niewielkiej odległości od krateru Ngorongoro i NCA znajduje się ponadto wiele wartych odwiedzenia atrakcji o charakterze wybitnie geoturystycznym. Zdecydowanie do najważniejszych $z$ nich należy wulkaniczny masyw Kilimandżaro (5895 m n.p.m.), będący najwyższą górą Afryki i zarazem najwyższą samotną górą Ziemi. Podobnie jak krater Ngorongoro jest on ściśle związany z ewolucją ryftu Gregory'ego. Wulkan ten zaczął się kształtować około 1,8-1,5 mln lat temu, a zatem już po zakończeniu aktywności w Ngorongoro. Zakończył on swą działalność zaledwie 10 tysięcy lat temu (Żaba 2005). Warto udać się też do Parku Narodowego Arusha, na terenie którego znajduje się najwyższy czynny wulkan Afryki - Meru (4568 m n.p.m.; Fig. 2, Dawson 2008).

Na południowym wschodzie, w pobliżu NCA znajduje się Park Narodowy Jeziora Manyara (Fig. 2), a na zachód od krateru Ngorongoro - Jezioro Wiktorii położone na wysokości ponad 1000 m n.p.m. Zajmując powierzchnię 68800 km² jest ono największym jeziorem Afryki. Oba jeziora odznaczają się tektoniczną genezą oraz zajmują określoną pozycję w obrębie wschodnioafrykańskiego systemu ryftowego. Z uwagi na niewątpliwe piękno krajobrazów i wyjątkowe bogactwo świata przyrodniczego obiekty te stanowią wysokiej rangi atrakcje geoturystyczne. 


\section{Geoturystyczna waloryzacja geostanowisk} Obszaru Chronionego Ngorongoro

Wybrane geostanowiska Obszaru Chronionego Ngorongoro i terenów przyległych poddano szczegółowej waloryzacji (Tab. 1,2). W tym celu wykorzystano metodyką opierającą się na punktacji szeregu szczegółowych czynników wpływających na atrakcyjność danego obiektu, zgrupowanych w czterech głównych kategoriach (Pereira et al. 2007, Brilha et al. 2009). Oprócz wartości naukowych są to również: wartości dodatkowe, użytkowe i ochrony. Pierwsze dwie kategorie można potraktować wspólnie jako wartość geologiczną danego obiektu. Zastosowanie takiego schematu pozwala uzyskać bardzo cenne dane do porównywania geostanowisk między sobą, obarczone stosunkowo niskim - jak na szacowanie wartości geoturystycznych - stopniem subiektywności (Pereia et al. 2010).

Krater Ngorongoro, jako największa i najważniejsza atrakcja geoturystyczna tego obszaru, uzyskał zdecydowanie najwyższą notę spośród wszystkich wziętych pod uwagę geostanowisk (Tab. 1, 2). Wykazuje on zatem największy potencjał geoturystyczny w obrębie analizowanego obszaru. Jednakże nie w każdej z czterech głównych kategorii obiekt ten uplasował się na pierwszym miejscu (por. Tab. 2). Zdecydowanie dominuje on pod względem wartości dodatkowych (Tab. 2), takich jak wartości estetyczne, ekologiczne oraz kulturowe (Tab. 1). Pod względem wartości naukowych najwyższą, niemalże identyczną ocenę uzyskały dwa geostanowiska: krater Ngorongoro oraz wąwóz Olduvai (por. Tab. 2). W pierwszym przypadku jest to związane ze szczególną pozycją tej największej niezniszczonej i niezalanej kaldery wulkanicznej na Ziemi, w obrębie wschodnioafrykańskiego systemu ryftowego (Żaba, Gaidzik 2011b). Wybitne odkrycia archeologiczne i ich znaczenie dla poznania ewolucji ludzkości, dokonane w obrębie wąwozu Olduvai wpłynęły na jego wysoką punktację pod względem wartości naukowych. Ponadto wysoką notę uzyskał jedyny na kuli ziemskiej czynny wulkan karbonatytowy - Oldoinyo Lengai (por. Tab. 2). Szczególnie niską notę w tej kategorii uzyskała skała Nasera, posiadająca głównie wartości estetyczne oraz pewne wartości kulturowe i naukowe w zakresie archeologii, ale o zdecydowanie mniejszym znaczeniu niż wąwóz Olduvai.

Oprócz wartości naukowych, estetycznych, kulturowych czy ekologicznych geostanowisko powinno również spełniać kryteria związane z możliwością rozwoju ruchu turystycznego (cechy użytkowe oraz możliwości ochrony). W zastosowanej metodyce wzięto pod uwagę takie wskaźniki jak dostępność, widoczność, zagospodarowanie wartości geologicznych i innych, ochrona prawna, infrastruktura dodatkowa, integralność oraz odporność na zniszczenie w wyniku użytkowania (por. Tab. 1). Z przeprowadzonej waloryzacji wynika, iż najwyższymi wartościami użytkowymi cechują się najbardziej znane i najlepiej zagospodarowane geostanowiska: krater Ngorongoro, wąwóz Olduvai i rejon Laetoli (Tab. 2). Te obiekty stanowią niejako, „wizytówki” Obszaru Chronionego Ngorongoro stąd stopień ich udostępnienia, zagospodarowania i ochrony jest najwyższy ze wszystkich wziętych pod uwagę potencjalnych geostanowisk. Inaczej przedstawia się problem ich podatności na zniszczenie. Naj- bardziej odporne są duże formy, zazwyczaj te, które nie odznaczają się wybitnymi wartościami kulturowymi, np.: Oldoinyo Lengai, wąwóz Olkarien, czy krater Olmoti i Empakai (Tab. 2). Najbardziej podatne, a zatem zagrożone wzmożonym ruchem turystycznym są geostanowiska związane z kulturą, wartościami ekologicznymi, np. wąwóz Olduvai, rejon Laetoli (Tab. 2).

\section{Zagrożenia}

Pomimo stosunkowo wcześnie rozpoczętej działalności mającej na celu ochronę dziedzictwa przyrodniczego krateru Ngorongoro obszar ten był, jest i będzie narażony na różnego rodzaju zagrożenia zarówno naturalne, jak i antropogeniczne. Dotyczą one - niemalże w tym samym stopniu - różnych elementów przyrody ożywionej, obiektów przyrody nieożywionej oraz wartościach kulturowych. W latach 1984-1989 Obszar Chroniony Ngorongoro znajdował się na specjalnej Liście Obiektów Światowego Dziedzictwa Kulturowego i Przyrodniczego UNESCO, których najbardziej istotne wartości są w stanie poważnego zagrożenia (UNESCO/IUCN 2008).

Żywe procesy geologiczne związane ze wschodnioafrykańskim systemem ryftowym, będące jedną z największych atrakcji krateru Ngorongoro, mogą stanowić też pewne zagrożenie, wynikające zarówno z aktywności sejsmicznej, jak i wulkanicznej tego obszaru. Dotychczas nie jesteśmy w stanie przeciwdziałać tym zagrożeniom, a jedyna działalność władz NCA w tym względzie może polegać na monitorowaniu tych procesów.

Szczególnej ochrony w obrębie kaldery wymaga świat przyrody ożywionej. Wiele gatunków zwierząt i roślin występujących na tym obszarze jest w mniejszym lub większym stopniu zagrożonych wyginięciem. Do szczególnie narażonych należy przede wszystkim nosorożec czarny (Diceros bicornis), który został wpisany do czerwonej księgi gatunków zagrożonych wyginięciem Międzynarodowej Unii Ochrony Przyrody (w kategorii gatunków krytycznie zagrożonych). Wśród innych gatunków również wpisanych do czerwonej księgi (kategorie: zagrożone oraz podatne na zagrożenie wyginięciem) znajdują się między innymi: hipopotam nilowy (Hippopotamus amphibius), słoń afrykański (Loxodonta africana), lew (Panthera leo), gepard (Acinonyx jubatus), likaon (Lycaon pictus) i kot złocisty (Profelis aurata). Z występujących w kraterze gatunków ptaków do najbardziej zagrożonych wyginięciem według Międzynarodowej Unii Ochrony Przyrody należą białoszpon (Falco naumanni) i nikornik białosterny (Apalis karamojae) (http://www.iucnredlist.org/).

Świat przyrody ożywionej i nieożywionej krateru Ngorongoro jest wyjątkowo czuły na zagrożenia zarówno ze strony ludności miejscowej, jak i stale powiększającej się rzeszy turystów odwiedzających to miejsce.

\section{Podsumowanie}

Krater Ngorongoro z uwagi na swe wielkie, unikalne w skali światowej bogactwo przyrodnicze, a także wspaniale reprezentowane i czytelne ślady różnych procesów geologicznych (głównie tektonicznych i wulkanogenicznych) zasługuje na miano największej atrakcji geoturystycznej ryftu Gregory'ego, a także jednej z najważniejszych atrakcji Afryki Wschodniej, a nawet całego kontynentu. O wielkim zainteresowaniu obszarami, na których atrakcje przyrody ożywionej i nieożywionej łączą się z walorami kulturowymi, 
świadczy wzrastająca z roku na rok liczba turystów odwiedzających ten rejon. Wybitne walory tej lokalizacji zostały dobitnie potwierdzone przez wpisanie jej na Listę Obiektów Światowego Dziedzictwa Kulturowego i Przyrodniczego UNESCO oraz objęcie też innymi formami ochrony.

Każdego roku krater Ngorongoro jest odwiedzany przez rzesze turystów. Pomimo iż ich liczba stale rośnie, ruch turystyczny na tym obszarze jest ściśle skoncentrowany. Dzieje się tak z uwagi na powszechny obowiązek wynajmowania przewodnika oraz strażnika podczas zwiedzania większości obiektów NCA. W obrębie kaldery Ngorongoro przemieszczanie odbywa się wyłącznie wynajętymi, specjalnie przystosowanymi do tego celu samochodami terenowymi, które chronią turystów przed niebezpiecznymi zwierzętami żyjącymi w kraterze. Liczba miejsc noclegowych na tym obszarze jest ściśle określona i szczegółowo monitorowana.

Z przeprowadzonej waloryzacji wybranych dziewięciu geostanowisk z Obszaru Chronionego Ngorongoro i terenów przyległych wynika, że zdecydowanie najwyższym potencja- łem geoturystycznym odznaczają się krater Ngorongoro i wąwóz Olduvai. Wszystkie wzięte pod uwagę obiekty charakteryzują się stosunkowo wysokimi wartościami naukowymi i estetycznymi. Większość jednak - spośród tych mniej promowanych - uzyskała niskie noty w kategoriach dotyczących ochrony, turystycznego zagospodarowania i użytkowania.

Pomimo przestrzegania surowych zasad i reguł panujących w NCA, zarówno krater Ngorongoro, jak i żyjące w nim gatunki zwierząt i roślin są stale narażone na zagrożenia zarówno naturalne, jak i antropogeniczne. Te ostatnie są przez władze Obszaru Chronionego Ngorongoro ograniczane do minimum. Zagrożenia naturalne wiążą się przede wszystkim ze szczególnym położeniem tego obszaru w obrębie wschodnioafrykańskiego systemu ryftowego, co wiąże się ze wzmożoną aktywnością różnych procesów geologicznych. Do najbardziej niebezpiecznych należy duża aktywność wulkaniczna i sejsmiczna ściśle związana z procesami ryftogenezy prowadzącymi do kształtowania się i rozwoju wielkich rowów tektonicznych.

\section{References (Literatura):}

Brilha, J., Pereira, D., Pereira, P. (eds.), 2009. Intensive Course on Geodiversity and Geological Heritage Assessment Workbook. University of Minho, $47 \mathrm{pp}$.

Dawson, J.B., 2008. The Gregory Rift Valley and Neogene-Recent Volcanoes of Northern Tanzania. Geological Society, London, $102 \mathrm{pp}$.

Diez-Martín, F., Sánchez, P., Domínguez-Rodrigo, M., Mabulla, A., Barba, R., 2009. Were Olduvai Hominins making butchering tools or battering tools? Analysis of a recently excavated lithic assemblage from BK (Bed II, Olduvai Gorge, Tanzania). Journal of Anthropological Archaeology, 28: 274-289.

Duncan, R.C., 1989. Evolution, technology, and the natural environment: A unified theory of human history. Proceedings of the Annual Meeting, American Society of Engineering Educators: Science, Technology, \& Society: 14B1-11-14B1-20.

Estes, R.D., Atwood, J.L., Estes, A.B., 2006. Downward trends in Ngorongoro Crater ungulate populations 1986-2005: Conservation concerns and the need for ecological research. Biological Conservation, 131: 106-120.

Fishpool, L., Evans, M. (eds.), 2001. Important Bird Areas for Africa and Associated Islands. Priority Sites for Conservation. Pisces Publications and Birdlife International, Newbury and Cambridge, U.K. BLI Conservation Series No. 11.

Leakey, L., 1965. Olduvai Gorge. A Preliminary Report on the Geology and the Fauna 1951-1961. Cambridge University Press, Cambridge.

Leakey, M.D., 1967. Preliminary survey of the cultural material from Beds I and II, Olduvai Gorge, Tanzania. In: Bishop W.W., Clark J.D. (eds.), Background to Evolution in Africa. University of Chicago Press, Chicago: 417-446.

Leakey, M.D., 1971. Olduvai Gorge. Excavations in Bed I and II, 1960-63, vol. 3. Cambridge University Press, Cambridge.

Leakey, M.D., 1976. A summary and discussion of the archaeological evidence from Bed I and Bed II, Olduvai Gorge, Tanzania. In: Isaac G.L. Mc Cowan E.R. (eds.), Human Origins, Louis Leakey and the East African Evidence. W.A. Benjamin, Inc., Menlo Park: 431-460.

Leakey, M.D., 1979. Olduvai Gorge: My Search for Early Man. Williams Collins, London.

Manega P.C., 1993. Geochronology, Geochemistry and Isotopic Study of the Plio-Pleistocene Hominid Sites and the Ngorongoro Volcanic Highlands in Northern Tanzania. Ph.D. Dissertation, University of Colorado, Boulder.

Mora, R., de la Torre, I., 2005. Percussion tools in Olduvai Beds I and II (Tanzania): implications for early human activities. Journal of Anthropological Archaeology, 24: 179-192.
Pereira, P., Pereira, D., Caetano Alves, M.I., 2007. Geomorphosite assessment in Montesinho Natural Park (Portugal). Geographica Helvetica, 13, 159-168.

Pereira, P., Brilha, J., Pereira, D., Carcavilla, L., Amrikazemi, A., Bajada, S., Barreto, J.M., Bollati, I., Braga, N., Canilho, S., Carvalhido, R., Casinhas, P., Castro, I., Cumbe, A., Dias, N., Erhartic, B., Fraga Pereira, R., Gaidzik, K., Guimarães, R., Ghiraldi, L., Kozina, K., Lima, E., Lopes, E., Loureiro, C., Mantesso, V., Martin, S., Nekouie-Sadry, B., Pereira, S., Rocha, J., Sá Lemos, H., Schilling, M., Sousa, M., Tomsa, A.M., Torres, M., Welc, E. \& Zanoletti, E., 2010. Subjectivity and uncertainty in geological heritage quantitative assessment: results from fieldwork using a predefined numerical methodology. In: Mugge-Bartolovic V., Rohling H. \& Wrede V. (eds.), GeoTop 2010 - Geosites for the Public, Paleontology and Conservation of Geosites. Schriftenreihe der Deutschen Gesellschaft für Geowissenschaften, 66, Hannover: 114-115.

Tombazzi, G., 2003. New map of Ngorongoro Conservation Area. Maco Editions LLC, Italy.

UNESCO/IUCN, 2007. Ngorongoro Conservation Area (United Republic of Tanzania). Report of the WHC / IUCN Reactive Monitoring Mission May 2007.

UNESCO/IUCN, 2008. Ngorongoro Conservation Area (United Republic of Tanzania). Report of the WHC / IUCN Reactive Monitoring Mission May 2008.

UNESCO World Heritage Committee, 2005. Report on the 29th Session of the Committee, Paris.

Żaba, J., 2005. The Kilimanjaro Volcano-geotouristic attraction in Africa. Geotourism, 1 (2): 3-12.

Żaba, J., Gaidzik, K., 2010. Geoturystyka - nowa interdyscyplinarna dziedzina nauk o Ziemi. Biuletyn Naukowy Wrocławskiej Wyższej Szkoły Informatyki Stosowanej. Turystyka i Rekreacja, 1: 6-13.

Żaba, J., Gaidzik, K., 2011a. The Ngorongoro Crater as the biggest geotouristic attraction of the Gregory Rift (N Tanzania, Africa) - geographical setting. Geotourism, 1-2 (24-25): 3-26.

Żaba, J., Gaidzik, K., 2011b. The Ngorongoro Crater as the biggest geotouristic attraction of the Gregory Rift (Northern Tanzania, Africa) - geological heritage. Geotourism, 1-2 (24-25): 27-46.

Websites:

http://whc.unesco.org/en/

http://www.ngorongorocrater.org/welcome.html

http://www.iucnredlist.org/ 